\title{
Snack Bar Berbahan Dasar Ubi Ungu dan Kacang Merah sebagai Alternatif Selingan untuk Penderita Diabetes Mellitus
}

\section{Snack Bar Based on Purple Sweet Potato and Red Bean as an Alternative Snack for Diabetes Mellitus}

\author{
Cantika Zaddana*, Almasyhuri ${ }^{1}$, Sara Nurmala ${ }^{1}$, Tiara Oktaviyanti ${ }^{1}$
}

\begin{abstract}
ABSTRAK
Latar Belakang: Diabetes Mellitus (DM) didefinisikan sebagai suatu kumpulan gejala metabolik yang timbul pada seseorang yang disebabkan adanya peningkatan kadar glukosa darah di atas nilai normal. Penderita DM tetap harus mengonsumsi pangan yang cukup agar kebutuhan zat gizi nya terpenuhi. Dalam penelitian ini dibuat suatu produk olah pangan berupa snack bar sebagai salah satu pilihan selingan yang cocok untuk dikonsumsi oleh penderita DM. Snack bar yang dibuat berbahan baku ubi ungu yang memiliki kandungan serat yang tinggi serta memiliki aktivitas antioksidan karena kandungan senyawa antosianin didalamnya dan kacang merah yang memiliki kandungan zat gizi yang cukup lengkap, kandungan serat yang tinggi, serta nilai Indeks Glikemik (IG) yang rendah. Pengembangan produk pangan fungsional berbahan baku lokal seperti tepung kacang merah dan tepung ubi ungu juga sebagai upaya dalam mengurangi penggunaaan bahan impor seperti gandum di Indonesia.

Tujuan: Penelitian ini bertujuan untuk mendapatkan formula snack bar yang memenuhi persyaratan mutu, memiliki kandungan zat gizi ( $\mathrm{KH}$, protein, lemak), aktivitas antioksidan, gula pereduksi. serta senyawa aktif (antosianin dan serat) yang baik dikonsumsi oleh penderita DM.

Metode: Penelitian ini dilakukan dengan desain eskperimen secara random acak lengkap. Formula snack bar dibuat menjadi 4 dengan rasio antara tepung ubi ungu dan kacang merah yang berbeda yaitu F1 (100:0), F2 (90:10), F3 (80:20), dan F4 (70:30). Parameter yang diteliti pada studi ini adalah daya terima (kesukaan) panelis, proksimat (kadar air, kadar abu, KH, protein, dan lemak), aktivitas antioksidan, gula pereduksi, kadar antosianin, dan kadar serat pangan dari snack bar yang paling disukai. Hasil: Berdasarkan hasil analisis diketahui bahwa snack bar F3 adalah formula yang paling disukai oleh panelis. Fomula terpilih (F3) memenuhi persyaratan mutu fisik dan kandungan zat gizi yang baik yaitu protein $(7,823 \%)$, lemak $(4,38 \%)$ dan $\mathrm{KH}$ $(81,857 \%)$. Snack bar ini juga mengandung aktivitas antioksidan yang sangat kuat yaitu (34,079 ppm), kadar gula pereduksi $(3,56 \%)$, kadar antosianin $(11,45 \mathrm{mg} / \mathrm{kg})$, dan kadar serat $(16,32 \%)$.

Kesimpulan: Snack bar pada penelitian ini memiliki mutu fisik dan kimia yang sesuai dengan persyaratan mutu serta mengandung protein yang tinggi, lemak yang rendah, serta kandungan serat yang tinggi. Snack bar ini juga memiliki aktivitas antioksidan yang sangat kuat karena kandungan antosianinnya yang tinggi serta mengandung gula reduksi yang rendah sehingga snack bar ini layak untuk dikonsumsi oleh penderita diabetes mellitus.
\end{abstract}

Kata kunci: Snack Bar, Ubi Ungu, Kacang Merah, Diabetes Mellitus

\section{ABSTRACT}

Background: Diabetes Mellitus (DM) is collection of metabolic symptoms that arise in a person due to an increase in blood glucose level above normal. Diabetic people still have to consume enough amount of food so that their nutritional needs are met. This study has developed a processed food product in the form snack bar as an alternative snack that is suitable to be consumed for diabetic people. Snack bar made from purple sweet potato which has a high fiber content and antioxidant activity due to the anthocyanin compound in it and red bean which has adequate nutrient, high fiber content, and low glycemic index (GI). The development of functional food made from local raw materials such as purple sweet potato and red bean is also a way to reduce the use of imported material such as wheat in Indonesia.

Objectives: This study aimed to obtain a snack bar formula that meet quality requirements, contained sufficient nutrients (KH, protein, fat), has antioxidant activity, low glucose level, as well as active compounds (anthocyanin and dietary fiber) which are good for consumed by people with diabetes.

Methods: This research was conducted with completely randomized experimental design. The snack bar formulas were made into 4 different ratios of purple sweet potato flour and kidney bean flour, which are F1 (100:0), F2 (90:10), F3 (80:20), and F4 (70:30). The parameters measured in this study were panelist acceptance, proximate content (water, ash, KH, protein, and fat), antioxidant activity, glucose level, anthocyanin level, and dietary fiber from most preferred snack bar. 
Results: Analysis showed that snack bar F3 was the most preferred formula by panelists. The selected formula (F4) meet the requirements of physical quality and adequate nutritional content, which are protein (7.823\%), fat (4.38\%), and $\mathrm{KH}(81.857 \%)$. This snack bar also contained very strong antioxidant activity (34.079 ppm), low glucose level (3.56\%), anthocyanin level $(11.45 \mathrm{mg} / \mathrm{kg})$, and fiber content (16.32\%). According to these results, this snack bar was suitable to be consumed by people with diabetes mellitus.

Conclusions: The snack bar in this study has physical and chemical qualities in accordance with quality requirements and contain high protein, low fat, and high fiber content. This snack bar also has very strong antioxidant because its high anthocyanin content, as well as has low glucose level.

Keywords: Snack Bar, Purple Sweet Potato, Red Bean, Diabetes Mellitus

\author{
*Korespondensi: \\ cantika.zaddana@unpak.ac.id \\ Cantika Zaddana \\ ${ }^{1}$ Program Studi Farmasi, Universitas Pakuan \\ Jl Pakuan PO BOX 452, Tegalega, Kota Bogor, Indonesia \\ Diterbitkan oleh: Universitas Airlangga dan IAGIKMI
}

\section{PENDAHULUAN}

Diabetes Mellitus (DM) merupakan suatu kumpulan gejala metabolik yang timbul pada seseorang karena adanya peningkatan kadar glukosa darah di atas nilai normal. Penyakit ini disebabkan gangguan metabolisme glukosa akibat kekurangan insulin baik secara absolut maupun relatif. Kondisi tersebut terjadi ketika pankreas tidak dapat memproduksi insulin yang cukup atau karena tubuh yang tidak dapat secara efektif menggunakan insulin tersebut ${ }^{12}$. Menurut riset yang telah dilakukan menunjukkan bahwa prevalensi diabetes di Indonesia saat ini mencapai 6.9\% (12.191.564 orang) dari jumLah penduduk dan umumnya diderita oleh populasi dewasa (>18 tahun) dan diketahui bahwa Indonesia menempati peringkat ke tujuh untuk prevalensi penderita diabetes tertinggi di dunia ${ }^{34}$. Penderita DM tetap harus mengonsumsi pangan yang cukup agar kebutuhan zat gizi nya terpenuhi. Dalam rangka memenuhi kecukupan akan zat gizi didalam tubuh maka konsumsi pangan dibagi atas makanan utama dan selingan, namun penderita DM biasanya sulit untuk mendapatkan makanan selingan yang bergizi namun tetap dapat mengontrol kadar glukosa darahnya.

Ubi ungu adalah golongan ubi jalar yang saat ini sudah banyak dibudidayakan di Indonesia. Ubi ungu memiliki warna keunguan yang disebabkan oleh adanya pigmen antosianin yang dikandung didalamnya. Antosianin sebagai senyawa fitokimia memiliki karakterisitik larut dalam air dan dapat memberikan warna ungu alami sehingga aman untuk dikonsumsi56. Antosianin juga memiliki kemampuan antioksidan yang mampu menghambat kerja radikal bebas serta meningkatkan sekresi insulin sehingga bermanfaat dalam pengendalian kadar glukosa darah 7 . Snack bar dari ubi ungu memiliki nilai IG paling rendah yaitu 21.54 dibandingkan dengan ubi kuning dan ubi merah, sehingga ubi ungu menjadi bahan pangan yang baik untuk dikonsumsi oleh penderita $\mathrm{DM}^{8}$. Ubi ungu merupakan sumber karbohidrat kompleks namun rendah akan protein, sehingga dibutuhkan bahan pangan sumber protein lainnya seperti kacang merah ${ }^{9}$.

Kacang merah merupakan jenis kacangkacangan yang mengandung karbohidrat tinggi, kadar lemak yang lebih rendah, dan kandungan serat yang cukup baik. Kandungan serat pada kacang merah yaitu sebesar 2,1 g/100 g bahan ${ }^{9}$. Kacang merah juga diketahui memiliki nilai Indeks Glikemik (IG) yang rendah yaitu sebesar 26 dan merupakan yang paling rendah dalam jenis kacang-kacangan ${ }^{10}$. Selain mengandung serat yang cukup baik serta nilai IG yang rendah, kacang merah juga mengandung protein yang cukup tinggi yaitu sebesar 11 $\mathrm{g} / 100 \mathrm{~g}$ bahan ${ }^{9}$.

Pangan fungsional merupakan makanan alami atau pangan olahan yang mengandung satu atau lebih komponen senyawa bioaktif yang dapat memberikan efek yang menguntungkan bagi Kesehatan ${ }^{11}$. Kemajuan teknologi pangan telah menghasilkan berbagai produk pangan yang praktis dikonsumsi seperti snack. Produksi snack sebagai makanan selingan semakin bervariasi, namun snack yang dibuat biasanya tinggi akan kalori, lemak, dan karbohidrat sederhana. Kombinasi ubi ungu dan kacang merah sebagai bahan baku pangan fungsional seperti snack bar dibuat dengan harapan dapat menghasilkan produk makanan selingan yang tidak hanya disukai namun memiliki manfaat lebih untuk kesehatan yaitu tinggi protein, kaya serat, dan rendah glukosa sehingga makanan selingan tersebut baik untuk dikonsumsi oleh masyarakat terutama penderita DM. Pengembangan produk pangan fungsional berbahan baku lokal seperti tepung kacang merah dan tepung ubi ungu juga sebagai upaya dalam mengurangi penggunaaan bahan impor seperti gandum di Indonesia. Berdasarkan uraian yang telah dijelaskan maka membuat peneliti tertarik untuk membuat snack bar dengan bahan baku ubi ungu dan kacang merah sebagai alternatif makanan selingan bagi penderita DM.

\section{METODE}

Alat

Alat yang digunakan pada penelitian ini adalah timbangan digital analitik, mesh 100, Cawan uap, desikator, blender, mixer, spatula, sendok, pisau, talenan, loyang kue, sarung tangan plastik, oven, blender, wajan, kompor, labu ukur, labu kjeldahl, gelas ukur, beaker glass, pipet tetes, pipet volumetric, labu lemak, kertas saring, erlenmeyer, corong, rangkaian alat destilasi (labu destilasi, kondensor), microwave, krus, tanur, cawan, aluminium foil, stirrer magnetic, tabung reaksi, soxhlet, batu didih, beaker glass, batang pengaduk, $\mathrm{pH}$ meter, buret, statif, kapas dan Spektrofometer UV-Vis. 
Bahan

Studi ini menggunakan dua bahan baku yaitu ubi jalar ungu dan kacang merah serta menggunakan bahan-bahan tambahan lainnya yaitu air, telur, margarin, kurma, gula jagung Tropicana Slim, oat, perasa vanila, susu skim, aquadest, $\mathrm{HCl} 0,01 \mathrm{~N}, \mathrm{H}_{2} \mathrm{SO}_{4}$ pekat, $\mathrm{K}_{2} \mathrm{SO}_{4}$, $\mathrm{CuSO}_{4}, \mathrm{NaOH} 40 \%$, indikator metil red dan bromocresol hijau, $\mathrm{H}_{3} \mathrm{BO}_{3}, \mathrm{FeCl}_{3}$, methanol p.a, $\mathrm{SeO}_{2}$, vitamin $\mathrm{C}$, serbuk DPPH, pelarut $n$-Heksan, reagen luff schrool, $\mathrm{Na}_{2} \mathrm{CO}_{3}, \mathrm{~Pb}$ asetat, $\mathrm{KI} 20 \%, \mathrm{Na}_{2} \mathrm{~S}_{2} \mathrm{O}_{3} 0,1 \mathrm{~N}$, indikator amilum, aquadest steril, buffer fosfat.

\section{Tahapan Penelitian}

\section{Pengumpulan Bahan Baku dan Determinasi Tanaman}

Ubi jalar ungu dan kacang merah yang merupakan bahan baku pada penelitian ini didapatkan dari pasar tradisional di daerah Bogor, Jawa Barat. Kedua bahan baku tersebut selanjutnya dideterminasi dengan tujuan untuk memastikan bahwa baku yang digunakan homogen dan benar. Pengujian tersebut dilakukan di Pusat Penelitian Biologi, LIPI.

\section{Pembuatan Tepung Ubi Jalar Ungu}

Pengolahan ubi jalar ungu menjadi tepung memodifikasi prosedur dari Hardoko dkk, (2010)12. Prosedurnya dimulai dengan pengupasan kulit ubi jalar ungu. Ubi yang telah terpisah dari kulitnya dicuci dengan air mengalir selanjurnya diiris tipis dan dilakukan proses blansir selama 5 menit. Potongan ubi yang telah diblansir kemudian ditata di atas Loyang, setelah itu dikeringkan menggunakan oven pada suhu $60^{\circ} \mathrm{C}$ selama 90 menit. Ubi jalar ungu yang telah dikeluarkan dari oven didinginkan kemudai digiling dan disaring menggunakan mesh 100. Hasil yang diperoleh selanjutnya ditimbang dan dilakukan analisis kadar air, kadar abu, uji aktivitas antioksidan, dan uji antosianin.

\section{Pembuatan Tepung Kacang Merah}

Kacang merah yang diolah menjadi bentuk tepung memodifikasi prosedur dari Sutedja dkk, $(2015)^{13}$. Proses pengolahannya dimulai dengan pencucian kacang merah dengan air mengalir hingga bersih dari pengotor kemudian ditiriskan. Prosedur selanjutnya dilakukan blansir selama 5 menit dan dikeringkan dengan cara disangrai pada suhu $60^{\circ} \mathrm{C}$ selama 25 menit. Kacang merah yang telah kering digiling lalu diayak dengan mesh 100 . Hasil yang diperoleh ditimbang beratnya dan dilakukan pengujian kadar air, kadar abum dan uji aktivitas antioksidan.

\section{Perancangan Formula Snack bar}

Perancangan formula snack bar dalam penelitian ini memodifikasi dari penelitian Carella $(2012)^{14}$. Snack bar pada penelitian ini dibuat menggunakan bahan utama tepung ubi jalar ungu dan tepung kacang merah. Penggunaan bahan utama ini sebagai pengganti tepung terigu yang biasanya digunakan sebagai bahan utama pembuatan snack bar. Formulasi snack bar dibagi menjadi 4 variasi formula yang terdiri atas bahan baku dan bahan-bahan tambahan yang biasanya digunakan dalam pembuatan snack bar. Formulasi snack bar dapat dilihat pada Tabel 1.

Tabel 1 Formulasi Snack Bar

\begin{tabular}{llllll}
\hline \multirow{2}{*}{ Kegunaan Bahan } & \multirow{2}{*}{ Formula } & Berat Bahan $\mathbf{( g )}$ & & F3 & F4 \\
\cline { 3 - 6 } & & F1 & F2 & 80 & 70 \\
\hline Bahan Utama & Tepung Ubi Ungu & 100 & 90 & 20 & 30 \\
Bahan Utama & Tepung Kacang Merah & - & 10 & 15 & 15 \\
Isian Snack bar & Kurma & 15 & 15 & 5 & 5 \\
Pemanis & Gula Jagung & 5 & 5 & 15 & 15 \\
Emulsifier & Margarin & 15 & 15 & 20 & 20 \\
Perasa & Susu Skim & 20 & 20 & 20 & 20 \\
Pengikat & Telur & 20 & 20 & Qs & Qs \\
Perasa & Garam & Qs & Qs & 4 & 4 \\
Perasa & Perasa Vanila & 4 & 4 & 15 & 15 \\
Pemberi tekstur & Air & 15 & 15 & 10 & 10 \\
Isian Snack bar & Oat & 10 & 10 & 204 & 204 \\
\hline JumLah & & 204 & 204 & & \\
\hline
\end{tabular}

Keterangan:

Qs : secukupnya $( \pm 0.1 \mathrm{~g})$

Dalam satu formula (204 g) menghasilkan 8 buah snack bar. Berat satu snack bar $25 \mathrm{~g}$

\section{Pembuatan Snack bar}

Pembuatan snack bar dimulai dengan mencampur bahan kering yaitu tepung ubi jalar ungu, tepung kacang merah, garam, perasa vanilla, oat, gula jagung, dan kurma hingga merata. Bahan kering yang sudah dicampur kemudian ditambahkan dengan bahan basah yaitu margarin, air, dan telur yang telah dikocok sebelumnya. Pencampuran bahan basah dan bahan kering diuleni hingga menjadi kalis. Adonan yang telah kalis dicetak berbentuk persegi panjang dalam Loyang berukuran $22 \times 22 \times 7 \mathrm{~cm}$.
Snack bar yang telah dicetak kemudian dipanggang. Pemanggangan adonan dilakukan sebanyak dua tahap, yaitu pada tahap pertama menggunakan suhu $100^{\circ} \mathrm{C}$ selama 40 menit dan tahap kedua menggunakan suhu $120^{\circ} \mathrm{C}$ selama 20 menit. Pemanasan menggunakan suhu rendah dengan waktu yang lama bertujuan untuk mematangkan produk hingga bagian dalam tanpa menyebabkan gosong dibagian luar sedangkan pemanasan dengan suhu tinggi dalam waktu yang tidak lama bertujuan untuk mematangkan produk secara keseluruhan. 
Snack bar yang telah matang selanjutnya didinginkan pada suhu ruang selama 20 menit. Setelah itu dilakukan pengujian mutu fisik berupa penilaian terhadap rasa, warna, aroma, dan tekstur selanjutnya formula terpilih dilakukan pengujian mutu kimia yaitu uji kadar air dan kadar abu.

\section{Uji Hedonik}

Uji hedonik atau uji sensori dilakukan terhadap 30 orang panelis. Pada pengujian ini para panelis diminta tanggapannya terhadap kesukaan dan ketidaksukaan pada snack bar. Parameter yang diujikan yaitu warna, aroma, rasa, dan tekstur. Pengujian didasarkan pada lima skala hedonik 1-5 yaitu 1=sangat tidak suka, 2=tidak suka, $3=a g a k$ suka, $4=$ suka, $5=$ sangat suka. Hasil dari uji hedonik kemudian dianalisis dengan metode RAL dan Duncan menggunakan SPSS 17 for Windows. Formula terbaik berdasarkan hasil uji hedonik dilakukan analisis lanjut yaitu analisis proksimat, perhitungan angka kecukupan gizi (AKG), uji gula pereduksi, uji aktivitas antioksidan, analisis kadar antosianin, dan analisis kadar serat pangan.

\section{Analisis Proksimat Snack bar}

\section{Analisis Kadar Protein}

Analisis kadar protein dilakukan dengan menggunakan metode kjeldahl. Prosedurnya diawali dengan penimbangan sampel sebanyak $1 \mathrm{~g}$ dan dimasukkan kedalam labu kjeldahl. Sampel selanjutnya ditambahkan dengan $7 \mathrm{~g} \mathrm{~K}_{2} \mathrm{SO}_{4}, 0.8 \mathrm{~g} \mathrm{CuSO}_{4}$, dan larutan $\mathrm{H}_{2} \mathrm{SO}_{4}$ sebanyak $12 \mathrm{~mL}$ yang dilakukan di dalam lemari asam, kemudian didestruksi dengan pemanasan dalam keadaan mendidih hingga larutan menjadi hijau tosca. Larutan didinginkan selama 20 menit selanjutnya dilakukan penambahan akuades sebanyak $25 \mathrm{~mL}$ dan $\mathrm{NaOH} 40 \%$ sebanyak $50 \mathrm{~mL}$. Proses selanjutnya yaitu dilakukan penambahan $\mathrm{H}_{3} \mathrm{BO}_{3}$ sebanyak $30 \mathrm{~mL}$ yang dimasukkan ke dalam Erlenmeyer dengan ditambahkan indicator BCG-MR 3 tetes untuk menangkap destilat dari hasil destilasi. Tahapan terakhir yaitu larutan dititrasi dengan larutan $\mathrm{HCl} 0.01 \mathrm{~N}$ hingga terjadi perubahan warna menjadi merah muda seulas. Kadar protein dihitung dengan rumus:

$$
\begin{aligned}
& \text { Protein (\%) }=\frac{(V a-V b) H C l \times N H C l \times 14.007 \times 6.25 \times 100 \%}{W \times 1000} \\
& \text { Keterangan : } \\
& \mathrm{V}_{\mathrm{A}}=\mathrm{mL} \mathrm{HCl} \text { untuk titrasi sampel } \\
& \mathrm{V}_{\mathrm{B}} \quad=\mathrm{mL} \mathrm{HCl} \text { untuk tirasi blanko } \\
& \mathrm{N}=\text { Normalitas } \mathrm{HCl} \text { standar yang } \\
& \text { digunakan } \\
& 14.007=\text { Berat atom nitrogen } \\
& 6.25=\text { Faktor konversi protein } \\
& \mathrm{W} \quad=\text { Berat sampel dalam } \mathrm{g}
\end{aligned}
$$

\section{Analisis Kadar Lemak}

Pengujian kadar lemak dilakukan dengan menggunakan metode Soxhlet. Tahap awal pengujian yaitu dilakukan pemanasan labu lemak ke dalam ooven selama 30 menit pada suhu $100-105^{\circ} \mathrm{C}$. Labu lemak selanjutnya didinginkan dalam desikator dan ditimbang bobotnya. Tahapan selanjutnya yaitu dilakukan penimbangan sampel snack bar sebanyak $25 \mathrm{~g}$ kemudian sampel tersebut dibungkus dengan menggunakan kertas saring dan dimasukkan ke dalam tabung ekstraksi Soxhlet yang telah dihubungkan dengan labu lemak berisi batu didih. Sampel diekstraksi dengan pelarut n-heksana sebanyak $250 \mathrm{~mL}$ selama \pm 6 jam. Ekstrak lemak hasil dari ekstraksi selanjutnya didestilasi selama \pm 30 menit untuk memisahkan antara lemak dengan pelarut $n$-heksan, lalu destilat lemak yang diperoleh dikeringkan menggunakan oven pengering pada suhu $150^{\circ} \mathrm{C}$ selama 30 menit. Sampel yang telah dikeluarkan dari oven selanjutnya didinginkan dan ditimbang hingga bobotnya tetap. Kadar lemak dihitung dengan menggunakan persamaan :

$$
\begin{array}{ll}
\text { Kadar Lemak }(\%)= & \frac{W 2-W 1}{W} \times 100 \% \\
\text { Keterangan : } & =\text { Bobot sampel } \\
W^{W} & =\text { Bobot labu lemak } \\
W_{1} & =\text { Bobot labu+lemak setelah dioven }
\end{array}
$$

\section{Analisis Kadar Air}

Penetapan kadar air pada tepung ubi ungu, tepung kacang merah, dan snack bar dilakukan dengan menggunakan metode gravimetri. Prosedur pengujian diawali dengan pengovenan cawan selama 30 menit pada suhu $100-105^{\circ} \mathrm{C}$. Cawan yang telah dikeluarkan dari oven kemudian didinginkan dalam desikator untuk menghilangkan uap air untuk selanjutnya ditimbang (A). Sampel didalam cawan yang sudah dikeringkan ditimbang sebanyak $2 \mathrm{~g}$ (B) kemudian sampel beserta cawan tersebut dioven pada suhu $100-105^{\circ} \mathrm{C}$ selama 6 jam. Sampel kemudian didinginkan dalam desikator selama 30 menit dan beratnya juga ditimbang (C). Tahapan ini diulangi hingga bobot konstan tercapai. Perhitungan kadar air dilakukan berdasarkan berat basah dengan menggunakan rumus:

$$
\begin{array}{cl}
\text { Kadar Air (\%) }=\frac{B-C}{B-A} & x 100 \% \\
\text { Keterangan : } & =\text { Berat cawan kosong }(\mathrm{g}) \\
\mathrm{A} & =\text { Berat cawan + sampel sebelum } \\
\mathrm{B} & \text { dikeringkan }(\mathrm{g}) \\
\mathrm{C} & =\text { Berat cawan + sampel setelah } \\
& \text { dikeringkan }(\mathrm{g})
\end{array}
$$

\section{Analisis Kadar Abu}

Pengujian kadar abu dilakukan dengan menggunakan tanur pada suhu tinggi. Tahapan awal yaitu memasukkan krus silikat ke dalam oven selama 30 menit pada suhu $100-105^{\circ} \mathrm{C}$. Tahapan selanjutnya adalah memasukkan krus silikat untuk didinginkan di dalam desikator untuk menghilangkan uap air dan selanjutnya ditimbang. Sampel tepung ubi ungu, tepung kacang merah, dan sampel snack bar yang disukai oleh panelis ditimbang sebanyak $2 \mathrm{~g}$ lalu dimasukkan ke dalam krus silikat yang telah dipijar dan ditara. Sampel dalam krus silikat selanjutnya dibakar di atas nyala pembakar hingga tidak berasap dan dilanjutkan dengan pengabuan di dalam tanur bersuhu $550-600^{\circ} \mathrm{C}$ hingga terjadi pengabuan sempurna. Tahapan berikutnya adalah memasukkan sampel yang sudah diabukan ke dalam desikator dan kemudian ditimbang. Tahap pembakaran dalam tanur diulangi hingga bobot yang konstan dicapai. Kadar abu dihitung dengan rumus: 
Kadar

Abu

(\%)

$\underline{\text { Bobot cawan setelah pengabuan- Bobot cawan kosong }} \times 100 \%$

\section{Analisis Kadar Karbohidrat}

Penentuan kadar karbohidrat dilakukan dengan metode by difference, yaitu dengan melibatkan perhitungan dari kadar air, kadar abu, kadar protein, dan kadar lemak. Berikut ini adalaj persamaan yang digunakan dalam menghitung kadar karbohidrat dengan metode by difference:

Karbohidrat $(\%)=100 \%-(\%$ kadar air+\%kadar abu+\%kadar protein+\%kadar lemak)

\section{Analisis Kandungan Zat Gizi Terhadap Angka Kecukupan Gizi Kelompok Usia 19-29 Tahun}

Penentuan takaran saji dilakukan untuk mengetahui kontribusi zat gizi snack bar bagi kelompok wanita dan pria dengan rentang usia 19-29 tahun. Perhitungan kontribusi zat gizi dilakukan dengan membandingkan jumLah zat gizi yang dikandung dalam satu takaran saji snack bar dengan angka kecukupan gizi (untuk kelompok usia 19-29 tahun) kemudian dikali 100\%. Angka kecukupan gizi snack bar dihitung berdasarkan nilai kecukupan gizi pada AKG $2013^{15}$.

\section{Uji Kadar Gula Pereduksi}

Penentuan Gula Pereduksi dilakukan dengan menggunakan Metode Luff Schoorl. Pengujian diawali dengan membuat larutan sampel dengan cara menimbang sampel sebanyak 5-10 g dan dimasukkan ke dalam labu ukur $250 \mathrm{~mL}$. Larutan sampel kemudian ditambahkan $\mathrm{Pb}$ asetat untuk penjernihan, kemudian ditambah $\mathrm{Na}_{2} \mathrm{CO}_{3}$ untuk menghilangkan kelebihan $\mathrm{Pb}$. Larutan sampel tersebut selanjutnya diambil dengan pipet sebanyak $10 \mathrm{~mL}$ dan dimasukkan kedalam erlenmeyer, lalu ditambahkan $25 \mathrm{~mL}$ reagen luff school serta batu didih. Larutan sampel kemudian didihkan selama 10 menit,dan diidinginkan.

Larutan blanko dibuat dengan cara mengambil larutan luff schrool sebanyak $25 \mathrm{~mL}$ dan ditambahkan akuades $25 \mathrm{~mL}$ yang dimasukan ke dalam erlenmeyer. Setelah ditambahkan beberapa batu didih, blangko dididihkan selama 10 menit, kemudian didinginkan. Larutan blanko dan larutan sampel diteteskan dengan KI $20 \%$ masing-masing $15 \mathrm{~mL}$ serta $\mathrm{H}_{2} \mathrm{SO}_{4} 25 \mathrm{~mL}$ sedikit demi sedikit. Larutan blanko dan sampel kemudian dititrasi dengan $\mathrm{Na}_{2} \mathrm{~S}_{2} \mathrm{O}_{3} \mathrm{O}, 1 \mathrm{~N}$ yang ditambah indikator amilum 3 $\mathrm{mL}$ sampai warna biru hilang. Kadar gula reduksi dihitung dengan rumus :

Gula Reduksi $(\%)=\frac{\text { AT X Fp }}{\text { Berat sampel } \times 1000} \times 100 \%$

Keterangan :

$$
\begin{array}{ll}
\text { AT } & =\text { Angka tabel Luff Schoorl } \\
\text { Fp } & =\text { Faktor pengenceran }
\end{array}
$$

\section{Uji Aktivitas Antioksidan}

\section{Pembuatan Larutan DPPH 1 mM}

Larutan DPPH dibuat dengan cara menimbang 39.432 mg serbuk. Serbuk tersebut dimasukkan ke dalam labu ukur 100 mL (sebelumnya labu ukur sudah dilapisi aluminium foil) dan ditambahkan larutan metanol p.a hingga batas dan dihomogenkan (sebelumnya labu ukur sudah dilapisi alumunium foil).

\section{Pembuatan Larutan Blanko}

Larutan blanko dibuat dengan cara mengambil larutan DPPH $1 \mathrm{mM}$ sebanyak $1 \mathrm{~mL}$ dengan pipet yang dimasukkan ke dalam labu ukur $10 \mathrm{~mL}$ (sebelumnya labu ukur sudah dilapisi aluminium foil). Larutan selanjutnya ditambahkan metanol sampai $10 \mathrm{~mL}$ lalu dihomogenkan. Larutan blanko diinkubasi pada suhu sekitar $25-30^{\circ} \mathrm{C}$ selama 30 menit.

\section{Larutan Standar Induk Vitamin C 100 ppm}

Larutan standar dibuat dengan cara menimbang vitamin C sebanyak $100 \mathrm{mg}$ kemudian dimasukkan ke dalam labu ukur $100 \mathrm{~mL}$ (sebelumnya labu ukur sudah dilapisi aluminium foil).. Sampel vitamin C selanjutnya ditambahkan methanol p.a sampai tanda batas (1000 ppm) lalu dihomogenkan. Tahapan selanjutnya adalah mengambil larutan induk vitamin $\mathrm{C}$ (1000 ppm) yang dipipet sebanyak $100 \mathrm{~mL}$, kemudian dimasukkan ke dalam labu ukur $100 \mathrm{~mL}$, dan dilarutkan dengan metanol p.a sampai tanda batas (100 ppm).

\section{Penetapan Panjang Gelombang Maksimum}

Penetapan panjang gelombang maksimum dilakukan dengan cara mengambil larutan DPPH sebanyak $1 \mathrm{~mL}$ yang dimasukan kedalam labu ukur (sebelumnya labu ukur sudah dilapisi aluminium foil) dan diencerkan sampai batas dengan metanol pada labu ukur $10 \mathrm{~mL}$. Larutan selanjutnya diinkubasi pada suhu kamar selama 30 menit selanjutnya serapannya diukur pada panjang gelombang 510-520 nm hingga diperoleh panjang gelombang maksimum.

\section{Penetapan Waktu Inkubasi Optimum}

Waktu inkubasi optimum ditetapkan dengan cara mengambil larutan induk standar vitamin C (100 ppm) sebanyak $1 \mathrm{~mL}$ yang dimasukkan ke dalam labu ukur $10 \mathrm{~mL}$. Larutan selanjutnya ditambahkan larutan DPPH $1 \mathrm{mM}$ sebanyak $1 \mathrm{~mL}$ dan diencerkan sekaligus dihomogenkan dengan metanol sampai tanda batas. Larutan diukur serapannya pada panjang gelombang maksimum yang telah diperoleh pada waktu 10, 20, 30, 40,50 , dan 60 menit. Waktu inkubasi optimum didapat pada serapan yang optimum.

\section{Pembuatan deret Larutan Vitamin C (Kontrol Positif)}

Deret standar vitamin $\mathrm{C}$ dibuat dalam beberapa konsentrasi yaitu 2 ppm, 4 ppm, 6 ppm, 8 ppm, dan 10 ppm yang diencerkan dari larutan induk 100 ppm. Larutan-larutan tersebut disiapkan di dalam labu ukur 10 $\mathrm{mL}$. Pada masing-masing labu ukur ditambah $1 \mathrm{~mL}$ larutan DPPH $1 \mathrm{mM}$, selanjutnya diencerkan dengan metanol p.a hingga tanda batas, dikocok dan diinkubasi pada suhu kamar selama waktu optimum. Serapannya diukur pada panjang gelombang maksimum dengan menggunakan spektrofotometer UV-Vis.

Pembuatan Larutan Uji snack bar , Larutan Uji Tepung Ubi Ungu, dan Larutan Uji Tepung Kacang Merah

Larutan uji dibuat dengan cara menghaluskan sampel snack bar dari formula terpilih, tepung ubi ungu, 
dan tepung kacang merah sebanyak $100 \mathrm{mg}$ yang dimasukan kedalam labu ukur $100 \mathrm{~mL}$ (sebelumnya labu ukur sudah dilapisi alumunium foil) dan diencerkan serta dihomogenkan dengan metanol p.a sampai batas (1000 ppm). Larutan uji dari masing-masing sampel dibuat deret konsentrasinya yaitu $5,10,15,20$, dan 25 ppm. Tahapan selanjutnya adalah labu ukur pada masing-masing konsentrasi ditambah $1 \mathrm{~mL}$ larutan DPPH dan diencerkan dengan methanol p.a. Larutan didalam labu ukur dikocok dan diinkubasi pada suhu kamar sesuai dengan waktu optimum yang diperoleh sebelumnya. Tahapan terakhir adalah pengukuran serapan sampel snack bar, tepung ubi ungu, dan tepung kacang merah pada panjang gelombang

$\%$ inhibisi $=\frac{\text { absorbansi blanko }- \text { absorbansi sampel }}{\text { absorbansi sampel }} \times 100 \%$

\section{Uji Kadar Antosianin}

Analisis kadar antosianin dilakukan pada tepung ubi ungu dan snack bar formula terpilih. Pengujian dilakukan di Laboratorium Saraswati Indo Genetech (SIG). Analisis kadar antosianin dilakukan dengan cara mengambil sampel sebanyak 1-5 g yang dimasukkan ke dalam tabung falcon. Sampel selanjutnya ditambahkan 25 $\mathrm{mL}$ akuades, vortex, dai dipanaskan ke dalam penangas pada suhu $60^{\circ} \mathrm{C}$ selama 20 menit. Selanjutnya sampel dimasukkan ke dalam labu ukur $50 \mathrm{~mL}$, sisa falcon dibilas dengan $10 \mathrm{~mL}$ akuades lalu disonikasi selama 1 jam, maksimum dengan menggunakan spektrofotometer UvVis.

\section{Uji antioksidan dengan larutan DPPH}

Pengujian antioksidan dilakukan dengan cara mengukur serapan dari deret larutan uji, deret kontrol positif vitamin $\mathrm{C}$ dan blanko pada panjang gelombang maksimum yang telah didapatkan. Nilai $\mathrm{IC}_{50}$ (Inhibition Concentration) diperoleh dari potongan garis antara $50 \%$ daya hambat dengan sumbu konsentrasi menggunakan persamaan linear $(y=b x+a)$, dimana $y=50$ dan $x$ menunjukan IC50. Nilai persentase hambatan terhadap DPPH dihitung dengan rumus sebagai berikut :

kemudian sampel ditera dengan akuades dan dihomogenkan. Larutan delanjutnya disentrifugasi dengan kecepatan $6000 \mathrm{rpm}$ selama 10 menit. Setelah disentrifugasi, dipipet sebanyak $5 \mathrm{~mL}$ filtrat jernih (bila tidak jernih saring dengan membrane filter $0,45 \mu \mathrm{L}$ ke dalam 2 labu ukur $25 \mathrm{~mL}$. labu perta,a dilarutkan dengan buffer $\mathrm{pH} 1$ hingga tanda tera lalu dihomogenkan dan labu yang kedua dilarutkan dengan buffer $\mathrm{pH} 4,5$ hingga tanda tera dan dihomogenkan. Larutan sampel kemudian diukur dengan Spektrofotometer UV-Vis pada panjang gelombang $520 \mathrm{~nm}$ dan $700 \mathrm{~nm}$ dengan akuades sebagai blanko. Perhitungan kadar antosianin menggunakan rumus sebagai berikut:

Kadar antosianin $(\mathrm{mg} / \mathrm{kg})=$

$$
\frac{((\text { Abs } 520 \mathrm{~nm}-A b s 700 \mathrm{~nm}) p H 1-(\text { Abs } 520 \mathrm{~nm}-\text { Abs } 700 \mathrm{~nm}) \mathrm{pH} 4,5) \times M W \times 1000 \times \mathrm{Fp} \times \mathrm{V}}{\varepsilon \times 1 \times \text { bobot sampel }}
$$

Keterangan :

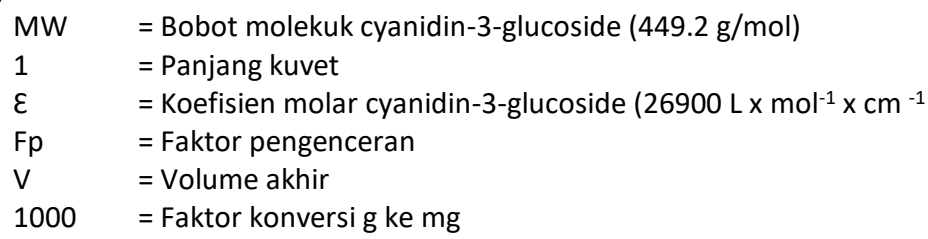

\section{Uji Kadar Serat Pangan}

Analisis kadar serat pangan juga dilakukan di Laboatorium Saraswati Indo Genetech (SIG). Pengujian dilakukan dalam 4 tahap yaitu pra preparasi, penetapan kadar serat pangan total, penetapan kadar serat pangan tak larut, dan penetapan kadar serat pangan larut.

\section{Pra Preparasi Sampel}

Sampel snack bar dihaluskan dan dikeringkan di dalam oven vakum pada suhu $70^{\circ} \mathrm{C}$ selama semalam. Setelah dikeringkan, sampel dihaluskan dengan mesh No. 40. Sampel selanjutnya disimpan dalam desikator hingga analisis dilakukan.

\section{Penetapan Kadar Serat Pangan Total}

Sampel ditimbang sebanyak 0,5-1 g dalam 2 tabung falcon $50 \mathrm{~mL}$, kemudian masing-masing sampel dipindahkan kedalam 2 gelas piala $400 \mathrm{~mL}$. Tahap selanjutnya sampel ditambahkan $40 \mathrm{~mL}$ larutan buffer MES-TRIS dan $50 \mu \mathrm{L}$ enzim $\alpha$-amilase kemudian diaduh hingga homogen dan mulut gelas piala ditutup dengan alumunium foil. Sampel selanjutnya diinkubasi dalam sahking water bath pada suhu $100^{\circ} \mathrm{C}$ selama 30 menit.
Larutan sampel yang telah dikeluarkan dari water bath kemudian didinginkan hingga suhu $60^{\circ} \mathrm{C}$, kemudian buka penutup alumuniu, foil, dan dispersikan gel yang terbentuk pada dasar gelas piala dengan pengaduk, lalu dibilas dengan $10 \mathrm{~mL}$ akuades. Sampel selanjutnya ditambahkan $100 \mu \mathrm{L}$ enzim protease dan diaduk kembali hingga tidak ada sampel yang menggumpal, kemudian ditutup kembali mulut gelas piala dengan alumunium foil, lalu diinkubasi dalam shaking water bath pada suhu $100^{\circ} \mathrm{C}$ selama 30 menit.

Tahap selanjutnya yaitu ditambahkan $5 \mathrm{~mL} \mathrm{HCl}$ $0,561 \mathrm{M}, \mathrm{pH}$ sampe diatur hingga $\mathrm{pH}$ nya 4,1-4,6 dengan larutan $\mathrm{NaOH} 1 \mathrm{M}$ atauh $\mathrm{HCl} 1 \mathrm{M}$. Sampel kemudian ditambahkan $200 \mu \mathrm{L}$ enzim amyloglukosidase dan diaduk hingga homogen, selanjutnya mulut gelas piala ditutup kembali dengan alumunium foil. Larutan sampel diinkubasi dalam shaking water bath pada suhu $60^{\circ} \mathrm{C}$ selama 30 menit dan ditambahkan dengan $225 \mathrm{~mL}$ etanol $95 \%$ bersuhu $60^{\circ} \mathrm{C}$, kemudian diaduk hingga homogen dan ditutup kembali dengan alumunium foil.

Larutan sampel didiamkan pada suhu ruang selama 1 jam lalu disaring dengan kertas saring tak berabu dan residunya dicuci dengan $2 \times 15 \mathrm{~mL}$ etanol $78 \%$, 
2×15 mL etanol 95\%, dan $2 \times 15 \mathrm{~mL}$ aseton, lalu kertas saring dikeringkan pada oven dengan suhu $103^{\circ} \mathrm{C}$. kertas saring yang berisi residu masing-masing ditimbang dan dihitung bobot abu pada hasil residu pertam dan bobot protein pada hasil residu kedua.

\section{Penetapan Kadar Serat Pangan Tak Larut}

Sampel snack bar yang telah di pra preparasi ditimbang secara duplo masing-masing sebanyak 0,5-1 g dalam 2 tabung falcon $50 \mathrm{~mL}$. Masing-masing sampel kemudian dipindahkan ke dalam 2 gelas piala $40 \mathrm{~mL}$. Sampel selanjutnya ditambahkan $40 \mathrm{~mL}$ larutan buffer MES-TRIS dan $50 \mu \mathrm{L}$ enzim $\alpha$-amilase, diaduk hingga homogen dan ditutup mulut gelas piala dengan alumunium foil, lalu diinkubasi dalam shaking water bath pada suhu $100^{\circ} \mathrm{C}$ selama 30 menit. Larutan sampel selanjutnya didinginkan hingga suhu $60^{\circ} \mathrm{C}$, kemudian gel yang terbentuk pada dasar gelas piala didispersikan dengan pengaduk lalu dibilas dengan $10 \mathrm{~mL}$ akuades. Sampel ditambahkan $100 \mu \mathrm{L}$ enzim protease, diaduk kembali hingga tidak ada sampel yang menggumpal, mulut gelas piala ditutup kembali dengan alumunium foil dan diinkubasi dalam shaking water bath pada suhu $100^{\circ} \mathrm{C}$ selama 30 menit. Sampel yang telah dikeluarkan dari water bath kemudian ditambahkan $5 \mathrm{~mL} \mathrm{HCL} 0,561 \mathrm{M}$ dan diatur $\mathrm{pH}$ sampel hingga $\mathrm{pH}$ nya 4,1-4,6 dengan larutan $\mathrm{NaOH} 1 \mathrm{M}$ atau $\mathrm{HCl} 1 \mathrm{M}$. Larutan sampel ditambahkan 200 $\mu \mathrm{L}$ enzim amyloglukosidase dan diaduk hingga hoomogen, kemudian ditutup kembali dengan alumunium foil, dan diinkubasi dalam shaking water bath pada suhu $60^{\circ} \mathrm{C}$ selama 30 menit. Sampel dikeluarkan kemudian disaring dengan kertas saring yak berabu, dicuci dengan $2 \times 10 \mathrm{~mL}$ akuades bersuhu $70^{\circ} \mathrm{C}$ lalu dikumpulkan filtat dan larutan pencuci untuk penetapan serat pangan larut (A). Residu dicuci dengan masingmasing $2 \times 10 \mathrm{~mL}$ etanol $95 \%$ dan $2 \times 10 \mathrm{~mL}$ aseton. Kertas saring lalu dikeringkan dalam oven pada suhu $103 \pm 2^{\circ} \mathrm{C}$. Kertas saring yang berisi residu kemudian ditimbang dan dihitung bobot abu pada hasil residu pertam dan bobot protein pada hasil residu kedua.

\section{Penetapan Kadar Serat Pangan Larut}

Filtrat pada pengujian serat pangan tak larut ditambahkan 4 kali volume etanol $95 \%$ bersuhu $60^{\circ} \mathrm{C}$ (etanol tersebut juga digunakan untuk membilas erlenmeyer penampung). Larutan didiamnkan pada suhu ruang selama 1 jam kemudian disaring dengan kertas saring tak berabu dan encapannya dicuci dengan $2 \times 15 \mathrm{~mL}$ etanol $78 \%$, $2 \times 15 \mathrm{~mL}$ etanol $95 \%$, dan $2 \times 15 \mathrm{~mL}$ aseton. Kertas saring kemudian dikeringkan dalam oven pada suhu $103 \pm 2^{\circ} \mathrm{C}$ lalu ditimbang masing-masing kertas saring yang berisi residu tersebut kemudian dihitung bobot abupada hasil residu pertam dan bobot protein pada hasil residu kedua. Larutan blanko dibuat seperti pengerjaan sampel untuk masing-masing penetapan serat pangan total, serat pangan larut, maupun serat pangan tak larut kemudian dihitung bobot abu pada hasil residu pertama dan bobot protein pada hasil residu kedua. Perhitungan kadar serat menggunakan rumus sebagai berikut:
Bobot abu (A) (g) = (Bobot cawan + abu) - Bobot cawan kosong

\begin{tabular}{|c|c|}
\hline Bobot protein $(\mathrm{P})(\mathrm{g})=\frac{V p \times N p \times f k \times 14.007}{1000}$ & $\begin{array}{ll}\text { Blanko }(g)=R_{B}-P_{B}-A_{B} & 1000\end{array}$ \\
\hline \multicolumn{2}{|c|}{$\begin{array}{l}\text { Kadar serat pangan larut, tak larut, total }(\%)=\frac{R-A-P-B}{W} \text { x } \\
100 \%\end{array}$} \\
\hline \multicolumn{2}{|c|}{ Keterangan : } \\
\hline $\mathrm{Vp}$ & $\begin{array}{l}=\text { Volume penitaran larutan } \mathrm{HCl} 0,2 \mathrm{~N} \\
(\mathrm{~mL})\end{array}$ \\
\hline $\mathrm{Np}$ & $=$ Normalitas larutan $\mathrm{HCl} \mathrm{0,2} \mathrm{N}$ \\
\hline $\mathrm{Fk}$ & = Faktor konversi protein \\
\hline $\mathrm{R}$ & = Bobot rata-rata residu sampel (g) \\
\hline A & = Bobot abu sampel (g) \\
\hline$P$ & $=$ Bobot protein sampel (g) \\
\hline W & = Bobot rata-rata sampel (g) \\
\hline B & = Bobot blanko (g) \\
\hline $\mathrm{R}_{\mathrm{B}}$ & $=$ Bobot rata-rata residu blanko $(\mathrm{g})$ \\
\hline $\mathrm{P}_{\mathrm{B}}$ & = Bobot protein blanko $(\mathrm{g})$ \\
\hline$A_{B}$ & = Bobot abu blanko (g) \\
\hline
\end{tabular}

\section{HASIL DAN PEMBAHASAN}

\section{Hasil Determinasi Ubi Ungu dan Kacang Merah}

Bahan utama yaitu ubi ungu dan kacang merah dilakukan determinasi di Pusat Penelitian Biologi, LIPI, Bogor. Hasil determinasi tersebut menunjukkan bahwa dua bahan baku yang digunakan dalam penelitian ini adalah ubi jalar ungu dengan jenis (Ipomoea batatas (L.) Lam. dan kacang merah dengan jenis (Phaseolus vulgaris L.)

\section{Pembuatan Tepung Ubi Jalar Ungu}

Ubi Ungu dalam pembuatan snack bar ini dibuat dalam bentuk tepung. Pembuatan tepung bertujuan untuk membentuk tekstur yang diinginkan, yaitu tidak terlalu basah dan tidak terlalu lunak. Tepung ubi ungu digunakan sebagai bahan utama dari pembuatan snack bar yang bertujuan untuk meningkatkan kandungan zat gizi serta aktivitas antioksidan pada snack bar.

Pengolahan ubi jalar ungu menjadi tepung ini diawali dengan melakukan pengupasan pada kulit ubi jalar ungu yang kemudian dicuci di bawah air mengalir. Ubi jalar ungu dipotong sebesar $1 \mathrm{~cm}$ karena berdasarkan hasil pengujian trial dan error yang dilakukan oleh Husna (2010) ${ }^{16}$ ketebalan potongan sebesar $1 \mathrm{~cm}$ akan membuat ubi jalar ungu lebih cepat kering. Ketebalan yang berlebihan $(>1 \mathrm{~cm})$ menyebabkan penyebaran panas yang kurang merata, sedangkan potongan ubi jalar ungu yang ketebalannya $<1 \mathrm{~cm}$ dapat menyebabkan senyawa antosianin mudah terdegradasi karena panas. Setelah dilakukan pemotongan dilanjutkan dengan blansir uap selama 5 menit dan ditiriskan.

Proses blansir dalam pembuatan tepung ubi ungu ini berfungsi untuk mencegah pencoklatan saat penepungan. Selain itu, blansir juga dapat menginaktivasi enzim-enzim oksidatif yang dapat mengakibatkan perubahan karakteristik, seperti warna, bau, rasa, dan tekstur ${ }^{17}$. Irisan ubi jalar ungu kemudian dikeringkan di dalam oven dengan suhu $60^{\circ} \mathrm{C}$ hingga kering, Kemudian dihaluskan mengunakan blender, lalu diayak menggunakan ayakan berukuran 100 mesh. Berikut 
adalah Gambar dari hasil pembuatan tepung ubi jalar ungu

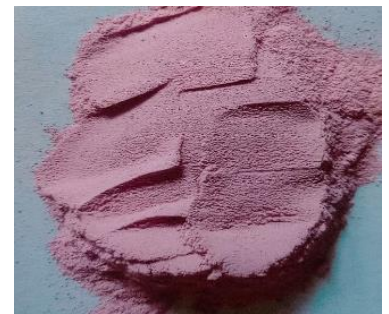

Gambar 1. Tepung Ubi Jalar Ungu
Setelah pembuatan tepung ubi jalar ungu, dilakukan analisis sifat fisik berupa penilaian sensoris terhadap rasa, warna, aroma dan tekstur. Hasil analisis sifat fisik pada tepung ubi ungu dapat dilihat pada tabel berikut.

Tabel 2. Sifat Fisik Tepung Ubi Jalar Ungu

\begin{tabular}{ll}
\hline Parameter & Pengamatan \\
\hline Rasa & Agak manis \\
Warna & Ungu \\
Aroma & Khas ubi ungu \\
Tekstur & Halus \\
\hline
\end{tabular}

\section{Pembuatan Tepung Kacang Merah}

Bahan utama kacang merah pada penelitian ini juga diolah menjadi bentuk tepung. Penambahan bahan tepung kacang merah dalam pembuatan snack bar bertujuan untuk meningkatkan kandungan protein, serat, serta aktivitas antioksidan pada snack bar.

Pembuatan tepung kacang merah ini diawali dengan proses pencucian kacang merah dengan air mengalir hingga bersih, lalu kacang merah yang telah bersih diblansir selama 5 menit, Proses blansir dalam pembuatan tepung kacang merah ini berfungsi untuk menginaktivasi enzim-enzim oksidatif yang dapat mengakibatkan perubahan karakteristik, seperti warna, bau, rasa, dan tekstur ${ }^{17}$. Setelah proses blansir, kacang merah dikeringkan dengan cara disangrai. Metode sangrai dilakukan dengan memanaskan bahan/sampel secara langsung dengan alat penyangrai yang dalam prosesnya juga dengan pengadukan sehingga panas yang diterima bahan akan lebih merata. Berdasarkan penelitian yang dilakukan oleh Sutedja dkk, (2015) ${ }^{13} \mathrm{kadar}$ air yang terkandung dalam tepung kacang merah dengan menggunakan metode sangrai memiliki kadar air yang lebih kecil (4,65\%) dibandingkan dengan kadar air tepung kacang merah metode oven $(7,79 \%)$. Lalu setelah kacang merah kering, dilakukan penggilingan menggunakan blender lalu tepung kacang merah diayak dengan ayakan mesh 100. Berikut adalah gambar dari hasil pembuatan tepung kacang merah.

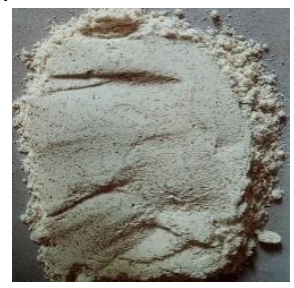

Gambar 2. Tepung Kacang Merah

Setelah pembuatan tepung kacang merah, dilakukan analisis sifat fisik berupa penilaian sensoris terhadap rasa, warna, aroma dan tekstur tepung. Hasil analisis sifat fisik pada tepung kacang merah dapat dilihat pada tabel berikut

Tabel 3. Sifat Fisik Tepung Kacang Merah

\begin{tabular}{ll}
\hline Parameter & Pengamatan \\
\hline Rasa & Tidak manis \\
Warna & Putih bintik merah \\
Aroma & Khas kacang merah \\
Tekstur & Halus \\
\hline
\end{tabular}

\section{Analisis Kadar Air dan Kadar Abu Pada Tepung Ubi Jalar Ungu dan Tepung Kacang Merah}

Analisis sifat kimia tepung ubi jalar ungu dan tepung kacang merah pada penelitian ini dilakukan meliputi kadar air dan kadar abu. Kadar air merupakan metode untuk menentukan banyaknya kandungan air yang terdapat dalam bahan yang dinyatakan dalam persen. Penetapan kadar air bertujuan untuk mengetahui batasan maksimal atau rentang besarnya kandungan air dalam bahan, sehingga bahan tidak mudah ditumbuhi oleh jamur dan mikroorganisme.

Kadar abu merupakan campuran komponen zat anorganik atau mineral sisa pembakaran dari senyawa organik. Penetapan kadar abu bertujuan untuk memastikan minimnya zat pengotor yang tertinggal dalam suatu pangan. Berikut adalah tabel hasil analisis Sifat Kimia pada tepung ubi jalar ungu dan tepung kacang merah 
Tabel 4. Sifat Kimia Tepung Ubi Jalar Ungu dan Tepung Kacang Merah

\begin{tabular}{lll}
\hline Sampel & Kadar Air (\%) & Kadar Abu (\%) \\
\hline Tepung ubi jalar ungu & 5,67 & 1,22 \\
Tepung kacang merah & 3,48 & 1,82 \\
\hline
\end{tabular}

Kadar air pada tepung dipengaruhi oleh beberapa faktor selama proses pengeringan, yaitu di antaranya waktu pengeringan, temperatur, serta kadar air dari bahan segarnya. Pengujian kadar air pada tepung ubi jalar ungu dan tepung kacang merah dilakukan secara duplo. Hasil kadar air rata-rata tepung ubi jalar ungu maupun tepung kacang merah pada penelitian ini memenuhi standar kadar air maksimal tepung yaitu maksimal $10 \%{ }^{18}$.

Kadar abu tepung ubi jalar ungu maupun tepung kacang merah pada penelitian ini tidak jauh berbeda jika dibandingkan dengan studi sebelumnya yaitu $1.72 \%$ untuk kadar abu pada sampel tepung ubi jalar ungu (Husna, 2010) dan 2.64\% untuk kadar abu pada sampel tepung kacang merah ${ }^{19}$.

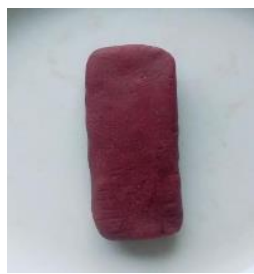

(A)

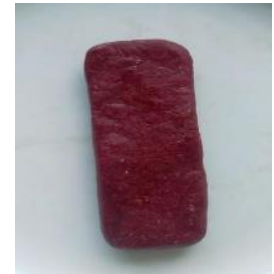

(B)

\section{Uji Organoleptik Snack bar}

Empat formula snack bar yang telah dibuat memiliki bentuk yang sama yaitu berbentuk batang, dengan warna ungu kecoklatan dan coklat keunguan. Masing-masing snack bar memiliki karakteristik yang sama satu sama lain jika ditinjau dari parameter warna, tekstur dan aroma. Persamaan tersebut terjadi karena bahan baku yang digunakan sama, namun terdapat perbedaan pada parameter rasa yang diakibatkan karena adanya perbedaan konsentrasi tepung ubi jalar ungu dan tepung kacang merah. Semakin banyak konsentrasi tepung kacang merah yang digunakan maka akan semakin memberikan rasa gurih pada snackbar yang dihasilkan. Hasil uji organoleptik terdapat pada Gambar 3 dan Tabel 5.

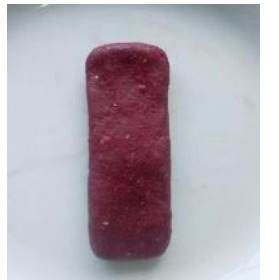

(C)

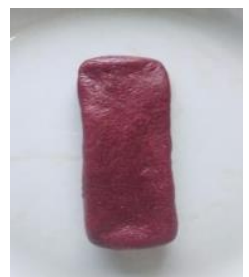

(D)

Gambar 3. Snack bar Ubi Jalar Ungu dan kacang Merah. (A) = F1; (B) = F2; (C) = F3; (D) = F4 Tabel 5. Hasil Uji Organoleptik Snack bar

\begin{tabular}{cllll}
\hline \multirow{2}{*}{ Formula } & \multicolumn{3}{l}{ Parameter } & \\
\cline { 2 - 5 } & Rasa & Warna & Aroma & Tekstur \\
\hline F1 & Manis & Ungu Kecoklatan & Vanilla Khas ubi ungu & Renyah \\
F2 & Manis & Coklat Keunguan & Vanilla khas ubi ungu kacang merah & Renyah \\
F3 & Manis & Coklat Keunguan & Vanilla khas ubi ungu kacang merah & Renyah \\
F4 & Manis & Coklat Keunguan & Vanilla khas ubi ungu kacang merah & Renyah \\
\hline
\end{tabular}

\section{Uji Hedonik}

Uji Hedonik atau analisis sensori dilakukan untuk mendapatkan 1 formula terbaik dari keempat formula yang diuji. Panelis uji hedonik pada penelitian ini
berjumLah 30 panelis pria dan wanita dengan rentang usia 19-29 tahun. Hasil uji hedonik dengan SPSS dapat dilihat pada Tabel 6

Tabel 6. Hasil Analisis Data Uji Hedonik Snack bar Menggunakan SPSS

\begin{tabular}{llllll}
\hline Snack bar & Rasa & Tekstur & Aroma & Warna & Rata-Rata \\
\hline F1 & $2,47^{\mathrm{a}}$ & $3,07^{\mathrm{a}}$ & $3,67^{\mathrm{a}}$ & $4,10^{\mathrm{c}}$ & 3,33 \\
F2 & $3,33^{\mathrm{b}}$ & $3,57^{\mathrm{b}}$ & $4,07^{\mathrm{b}}$ & $3,77^{\mathrm{b}}$ & 3,68 \\
F3 & $4,63^{\mathrm{c}}$ & $3,90^{\mathrm{c}}$ & $4,33^{\mathrm{b}}$ & $3,27^{\mathrm{a}}$ & 4,03 \\
F4 & $4,00^{\mathrm{d}}$ & $4,23^{\mathrm{d}}$ & $4,23^{\mathrm{b}}$ & $3,10^{\mathrm{a}}$ & 3,89 \\
\hline
\end{tabular}

Keterangan: Huruf superskrip yang sama pada kolom yang sama menunjukan tidak ada perbedaan yang signifikan antara formula

F1 = Tepung ubi jalar ungu: Tepung kacang merah (100:0)

F2 = Tepung ubi jalar ungu: Tepung kacang merah (90:10)

F3 = Tepung ubi jalar ungu: Tepung kacang merah (80:20)

F4 = Tepung ubi jalar ungu: Tepung kacang merah (70:30)

Berdasarkan hasil uji hedonik diketahui bahwa F3 memiliki nilai rataan yang paling besar. Oleh karena itu snack bar F3 adalah formula terpilih yang dilakukan pengujian selanjutnya yaitu analisis proksimat, perhitungan angka kecukupan gizi (AKG), uji gula pereduksi, uji aktivitas antioksidan, analisis kadar antosianin, dan analisis kadar serat pangan.

\section{Hasil Uji Proksimat Snack bar}

Analisis proksimat adalah suatu metode analisis kimia untuk mengidentifikasi kandungan zat makanan dari suatu bahan pangan. Tujuan dilakukannya analisis proksimat adalah untuk mengetahui kandungan air, abu, protein, lemak serta karbohidrat pada snack bar formula 
terpilih pada penelitian ini. Hasil analisis proksimat snack bar formula terpilih disajikan pada Tabel 7.

Tabel 7. Hasil Analisis Proksimat Sediaan Snack bar Formula 3

\begin{tabular}{lll}
\hline Parameter & Hasil Kadar (\%) & Syarat SNI 2973:2011 \\
\hline Kadar Air & 4,21 & Maks. 5\% \\
Kadar Abu & 1,73 & $1,6 \%$ \\
Kadar Protein & 7,823 & Min. 5\% \\
Kadar Lemak & 4,38 & - \\
Kadar Karbohidrat & 81,857 & - \\
\hline
\end{tabular}

\section{Kadar Air}

Kadar air adalah persentase kandungan air suatu bahan yang dapat dinyatakan berdasarkan berat basah (\%bb) atau berat kering (\%bk). Air merupakan komponen penting dalam bahan makanan karena air dapat mempengaruhi penampakan, tekstur, serta cita rasa makanan. Kandungan dalam bahan makanan menentukan acceptability, dan daya tahan bahan tersebut.

Berdasarkan hasil analisis, kadar air pada produk snack bar formula 3 adalah sebesar $4,21 \%$. Menurut penelitian yang dilakukan oleh Natalia (2010) ${ }^{20}$, produk snack bar yang terdapat di pasaran memiliki kadar air sebesar 8.7-11.4 sehingga kadar air snack bar pada penelitian ini diketahui lebih rendah dari pada kadar air snack bar yang terdapat di pasaran. Hal ini disebabkan karena penggunaan air dalam formula snack bar yang cukup rendah $(20 \mathrm{~g} / 204 \mathrm{~g})$, namun hasil kadar air snack bar ini memenuhi syarat mutu SNI (2011) ${ }^{21}$ untuk kadar air yaitu maksimal sebesar $5 \%$.

\section{Kadar Abu}

Kadar abu menunjukkan besarnya kandungan mineral dalam snack bar dan berhubungan erat dengan kemurnian serta kebersihan suatu bahan. Tujuan dilakukannya penentuan kadar abu adalah untuk menentukan baik atau tidaknya suatu pengolahan, mengetahui jenis bahan yang digunakan dan sebagai penentu parameter nilai gizi suatu bahan makanan. Hasil dari analisis kadar abu produk snack bar pada penelitian ini adalah sebesar 1,73\%. Jika dibandingkan dengan syarat SNI (2011) ${ }^{21}$, kadar abu pada snack bar formula terpilih sedikit lebih tinggi daripada persyaratan tersebut yaitu sebesar $1,6 \%$. Hal tersebut diduga karena kandungan mineral yang terdapat pada bahan baku snack bar cukup tinggi. Ubi jalar ungu mengandung mineral berupa kalsium (Ca) sebesar 87,8 ppm dan kandungan besi (Fe) sebesar 19,59 ppm². Bahan baku lain yang memiliki mineral yang tinggi adalah kacang merah. Kacang merah memiliki kandungan mineral berupa kalsium (Ca) sebesar $293 \mathrm{mg} / 100 \mathrm{~g}$, kalium (K) 360,7 $\mathrm{mg} / 100 \mathrm{~g}$, dan besi (Fe) 3,7 mg/100 $\mathrm{g}^{9}$. Meskipun kadar abu pada snack bar ini nilainya lebih tinggi daripada persyaratan mutu SNI tahun 2011 namun kadar abu pada snack bar yang dihasilkan ini lebih rendah daripada hasil analisis kadar abu dari snack bar di pasaran yaitu sebesar $2.2-2.5 \%^{20}$.

\section{Kadar Protein}

Protein merupakan salah satu zat gizi makro yang penting untuk tubuh. Potein dalam pangan berperan sebagai penyumbang energi dengan total kalori 4 kkal/g.
Tujuan dilakukannya analisis kadar protein adalah untuk mengetahui kandungan protein yang terkandung dalam snack bar formula terpilih. Hasil analisis snack bar pada penelitian ini adalah sebesar 7,823\%. Kadar protein pada penelitian ini lebih rendah dibandingkan dengan produk snack bar komersial yang beredar dipasaran yaitu dengan kisaran 15,5\%-15,8\% ${ }^{20}$. Hal tersebut diduga karena tepung ubi jalar ungu mengandung protein yang rendah yaitu $3,27 \%$ protein per $100 \mathrm{~g}$ bahan ${ }^{16}$ dan penggunaan tepung kacang merah yang tidak terlalu banyak yaitu hanya $20 \mathrm{~g}$ dalam satu formula $(204 \mathrm{~g})$. Meskipun demikian, hasil yang diperoleh menunjukan bahwa snack bar telah memenuhi persyaratan mutu biskuit menurut SNI tahun 2011 yaitu mengandung protein minimal $5 \%{ }^{21}$.

\section{Kadar Lemak}

Hasil analisis kadar lemak pada snack bar dalam penelitian ini adalah sebesar 4,38\%. Menurut studi yang ditelah dilakukan sebelumnya pada produk snack bar di pasaran diketahui bahwa snack bar tersebut memiliki kadar lemak sebesar $12.1-16.7 \%{ }^{20}$ sehingga kadar lemak snack bar pada penelitian ini dapat dikatakan lebih rendah dibandingkan dengan kadar lemak snack bar pasaran. Kandungan lemak yang rendah pada snack bar ini diduga karena bahan baku yang digunakan yaitu tepung ubi ungu yang mengandung sedikit lemak. Studi yang dilakukan oleh Husnah (2010) menunjukkan bahwa kandungan lemak pada tepung ubi ungu hanya sebesar $0,89 \%^{16}$. Tepung kacang merah sebenarnya merupakan sumber lemak karena mengandung lemak sebesar $6,60 \%{ }^{23}$ namun penggunaannya dalam pembuatan snack bar ini tidak terlalu banyak sehingga kandungan lemak pada snack bar penelitian ini rendah.

\section{Kadar Karbohidrat}

Berdasarkan hasil analisis diketahui bahwa kadar karbohidrat pada snack bar formula terpilih sebesar $81,857 \%$. Kadar karbohidrat yang cukup besar ini dapat disebabkan oleh kandungan karbohidrat yang cukup tinggi pada bahan baku yang digunakan. Hasil ini didukung oleh penelitian yang dilakukan Husnah (2010) yang diperoleh kandungan karbohidrat sebesar 86,66 $\mathrm{g} / 100 \mathrm{~g}^{16}$ pada tepung ubi ungu nya. Kandungan ini cukup tinggi namun karbohidrat yang terkandung dalam ubi jalar ungu merupakan karbohidrat kompleks karena diketahui bahwa snack bar yang terbuat dari ubi jalar ungu memiliki nilai IG yang rendah yaitu $21,54^{8}$. Tepung kacang merah juga memiliki jumlah karbohidrat yang cukup tinggi yaitu sebesar $67,50 \mathrm{~g} / 100 \mathrm{~g}^{23}$, oleh karena itu penggunaan kedua bahan baku tersebut yang diduga menyumbang komponen karbohidrat terbesar pada snack bar yang dihasilkan. 


\section{Hasil Kandungan Zat Gizi Snack bar Terhadap AKG Kelompok Usia 19-29 Tahun}

Kecukupan gizi dipengaruhi oleh faktor umur, jenis kelamin, aktivitas fisik, berat dan tinggi badan, genetika serta keadaan hamil dan menyusui. Angka kecukupan gizi merupakan kecukupan rata-rata zat gizi sehari yang digolongkan berdasarkan umur, jenis kelamin, ukuran tubuh, aktivitas fisik, keadaan fisiologis dan genetik yang dinilai cukup untuk memenuhi hampir kebutuhan semua orang dan untuk mencapai kesehatan yang maksimal15.

Pengaturan jadwal makan pada penderita DM pada prinsipnya tidak berbeda dengan orang yang non DM. Makanan yang dianjurkan untuk penderita DM tipe 2 dibagi dalam 3 porsi besar untuk makan pagi $(20 \%)$, siang
(30\%), sore $(25 \%)$, serta $2-3$ porsi makanan ringan (1015\%) dalam satu hari24. Berdasarkan Angka Kecukupan Gizi $2013^{15}$ dalam satu hari, AKG yang dianjurkan pada pria usia 19-29 tahun adalah $2725 \mathrm{kkal}$, sedangkan pada wanita usia 19-29 tahun adalah $2250 \mathrm{kkal}$. sehingga kebutuhan energi dari makanan selingan dalam $10 \%$ adalah sebesar 272,5 kkal untuk pria, 225 kkal untuk wanita. Kontribusi energi dan zat gizi snack bar terhadap AKG golongan usia 19-29 tahun dihitung dengan membandingkan kandungan energi dan zat gizi snack bar setiap takaran saji dengan AKG kelompok usia 19-29 tahun. Data perhitungan kontribusi energi dan zat gizi snak bar terhadap AKG kelompok usia 19-29 tahun dapat dilihat pada Tabel 8.

Tabel 8. Kontribusi Energi dan Zat Gizi Snack Bar terhadap AKG

\begin{tabular}{llll}
\hline Zat Gizi & Kandungan per Takaran saji (25 g) & \multicolumn{2}{c}{ \% AKG kelompok usia 19-29 } \\
\cline { 3 - 4 } & & $3,6526 \%$ & Wanita \\
\hline Energi (kkal) & $99,5346 \mathrm{kkal}$ & $3,1543 \%$ & $4,4237 \%$ \\
Protein (g) & $1,9557 \mathrm{~g}$ & $1,2032 \%$ & $1,46 \%$ \\
Lemak (g) & $1,095 \mathrm{~g}$ & $5,4571 \%$ & $6,7095 \%$ \\
Karbohidrat (g) & $20,4642 \mathrm{~g}$ & \\
\hline
\end{tabular}

Penderita diabetes mellitus tetap dianjurkan mengonsumsi pangan yang beragam dengan jumlah yang tepat. Makanan selingan dapat kita konsumsi sebagai upaya untuk membantu mencukupi kebutuhan zat gizi tubuh serta mengontrol glukosa darah sebagai upaya mencegah risiko komplikasi pada penderita DM tipe 2 . Takaran saji snack bar pada penelitian ini ditetapkan sebesar $25 \mathrm{~g}$ dalam 1 keping. Berat takaran saji tersebut mengacu pada takaran saji snack bar yang beredar dipasaran. Berdasarkan hasil analisis zat gizi yang dilakukan dapat disimpulkan bahwa snack bar ini dapat dikonumsi 2-3 keping dalam satu kali konsumsi dalam rangka memenuhi kebutuhan energi dari makanan selingan.

\section{Gula Pereduksi}

Besarnya nilai gula reduksi menggambarkan tingginya nilai glukosa didalam suatu pangan. Kadar glukosa yang tinggi dalam suatu pangan dapat meningkatkan kadar glukosa darah secara cepat. Kandungan gula reduksi pada snack bar ini mayoritas disumbangkan oleh tepung ubi jalar ungu karena kandungan pati nya yang besar. Menurut studi yang dilakukan oleh Nindrayani (2011), diketahui bahwa tepung ubi ungu mengandung gula reduksi sebesar 3,15 \pm $0,30 \%{ }^{25}$. Hasil uji menunjukkan bahwa kadar gula pereduksi yang terkandung di dalam sampel snack bar formula 3 adalah sebesar 3,56 \%. Hasil ini jauh berbeda jika dibandingkan dengan hasil penelitian yang dilakukan oleh Carella (2012) yang mendapatkan nilai gula pereduksi pada snack bar penelitiannya yaitu $9,68 \%{ }^{14}$, sehingga dapat dikatakan bahwa nilai gula pereduksi dalam snack bar ini cukup rendah.

Uji Aktivitas Antioksidan Pada Tepung Ubi Ungu, Tepung Kacang Merah dan Snack bar Formula Terpilih

Pengujian aktivitas antioksidan dilakukan menggunakan metode DPPH dimana DPPH berperan sebagai radikal bebas. Radikal bebas DPPH yang tidak memiliki pasangan elektron memiliki warna ungu. Warna ungu pada DPPH dapat memudar dan berubah menjadi warna kuning apabila serbuk dicampur dengan suatu bahan alam yang memiliki senyawa aktif yang dapat mendonorkan atom hidrogennya kepada radikal bebas $\mathrm{DPPH}^{26}$. Pengikatan atom hidrogen pada DPPH menyebabkan ikatan rangkap terkonjugasi berkurang sehingga terjadi penurunan intensitas warna dan absorbansi. Reaksi yang terjadi antara DPPH dan antioksidan dapat dilihat pada Gambar 4.

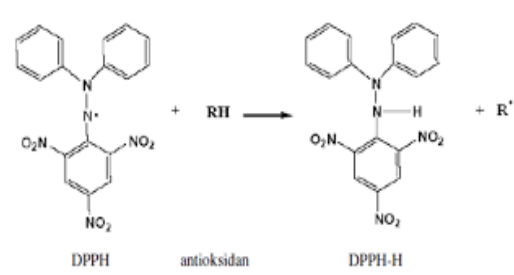

Gambar 4. Reaksi DPPH dengan Antioksidan (sumber : Syaifuddin, 2015)

Aktivitas antioksidan pada sampel tepung ubi jalar ungu, tepung kacang merah, dan snack bar formula terpilih dapat dilihat pada Tabel 9.

Tabel 9. Aktivitas Antioksidan Bahan Baku dan Larutan Pembanding

\begin{tabular}{lll}
\hline & Tabel 9. Aktivitas Antioksidan Bahan Baku dan Larutan Pembanding \\
\hline Sampel & $\begin{array}{l}\text { Aktivitas Antioksidan } \\
\text { (IC50 ppm) }\end{array}$ & Keterangan \\
\hline Kontrol Vitamin C & $7,284 \mathrm{ppm}$ & Sangat Kuat \\
Tepung Ubi Jalar Ungu & $48,2932 \mathrm{ppm}$ & Sangat Kuat \\
Tepung Kacang Merah & $50,3668 \mathrm{ppm}$ & Kuat \\
Snack bar Formula 3 & $34,079 \mathrm{ppm}$ & Sangat Kuat \\
\hline
\end{tabular}


Berdasarkan hasil pengujian, diketahui bahwa dari ketiga sampel ini memiliki aktivitas antioksidan yang berbeda-beda. Aktivitas antioksidan dalam ubi jalar ungu disumbangkan oleh senyawa fitokimia yaitu antosianin. Menurut penelitian yang dilakukan oleh (Ginting et al., 2011) tepung ubi jalar ungu mengandung antosianin sebesar $255,8 \mathrm{mg} / 100 \mathrm{~g}^{27}$. Antosianin memiliki kapasitas yang tinggi sebagai antioksidan karena kemampuannya menangkap radikal bebas dan menghambat peroksidasi lemak yang merupakan penyebab utama kerusakan pada sel yang berasosiasi dengan terjadinya penuaan dan penyakit degeneratif.

Parameter yang digunakan untuk mengetahui besarnya kemampuan senyawa sebagai antioksidan yaitu nilai $I_{50}$. Nilai $I_{50}$ adalah nilai konsentrasi dari antioksidan yang dibutuhkan untuk menangkap radikal bebas DPPH sebesar 50\% yang dapat diartikan yaitu semakin kecil nilai $\mathrm{IC}_{50}$ maka aktivitas peredaman radikal bebas semakin tinggi ${ }^{28}$. Nilai $\mathrm{IC}_{50}$ dapat diperoleh dari persamaan regresi linier yang menunjukkan hubungan antara konsentrasi larutan yang dinyatakan dengan $x$ dengan \% inhibisi yang dinyatakan dengan y. Konsentrasi sampel dihitung dengan antilog nilai $x$ yang diperoleh yaitu dengan cara memasukkan angka 50 sebagai y dalam persamaan regresi linier yang diperoleh dari grafik log konsentrasi dengan \%inhibisi. Semakin kecil nilai $I_{50}$ maka sampel tersebut semakin aktif sebagai senyawa antioksidan. Grafik aktivitas antioksidan pada sampel tepung ubi jalar ungu dapat diamati pada Gambar 5 di bawah ini.

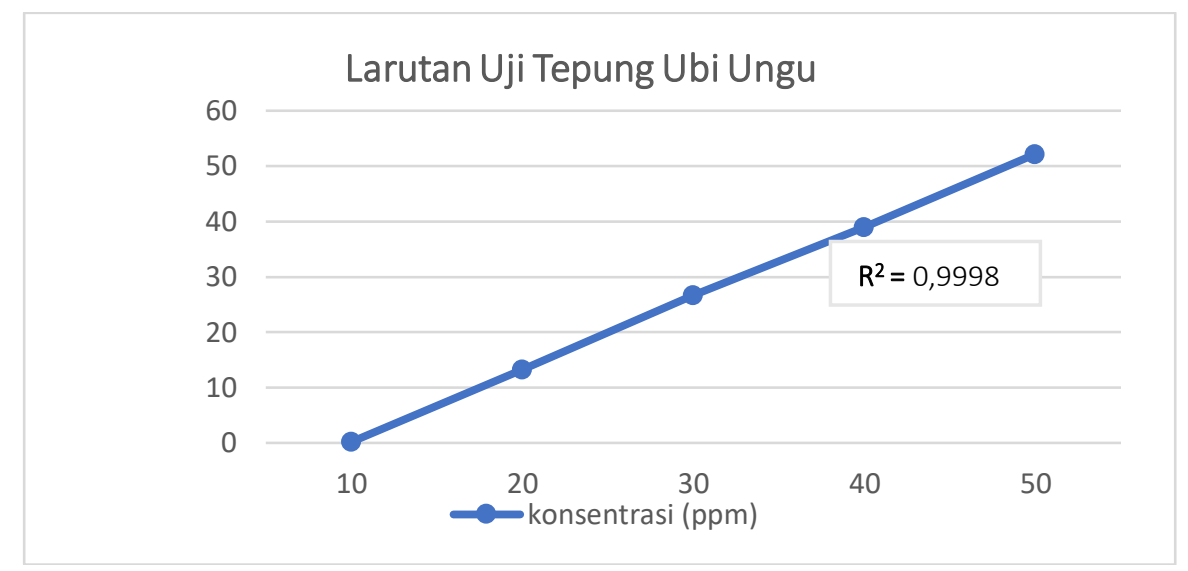

Gambar 5. Grafik konsentrasi dan \% inhibisi Tepung Ubi jalar Ungu

Gambar 5 menunjukkan bahwa bahwa persamaan regresi linier yang dihasilkan memiliki koefisien korelasi $\mathrm{R}^{2}=0,9998$ yang artinya memiliki nilai korelasi yang baik (mendekati 1). Nilai koefisien relasi $\left(R^{2}\right)$ menggambarkan linieritas konsentrasi terhadap \% inhibisi. Nilai koefisien relasi yang mendekati 1 menandakan bahwa dengan bertambahnya konsentrasi sampel maka semakin meningkat pula aktivitas antioksidannya. Persamaan regresi linier yang dihitung menggunakan Ms. Excel mendapatkan hasil persamaan yaitu $y=1,2972 x+(-12,6460)$ sehingga diperoleh nilai IC $C_{50}$ sebesar 48,29 ppm yang termasuk kedalam kategori aktivitas antioksidan sangat kuat ${ }^{28}$.

Pada sampel tepung kacang merah, diketahui bahwa aktivitas antioksidan yang dominan dalam kacang merah disumbangkan oleh kandungan flavonoid.
Flavonoid termasuk golongan antioksidan primer karena bersifat melepas atom hidrogen, menangkap radikal bebas, dan berfungsi sebagai pengelat logam. Selain flavonoid, kacang merah juga mengandung asam fitat. Asam fitat diketahui sebagai zat antigizi karena membentuk kompleks dengan beberapa mineral seperti besi. Besi termasuk golongan katalis logam yang dapat mempercepat terjadinya oksidasi. Adanya ikatan antara fitat dengan besi ini akan menurunkan kemampuan katalisis besi pada reaksi-reaksi oksidatif dan menghindari terbentuknya hidroksil radikal karena proses oksidasi. Pada penelitian Arinanti (2018) diketahui kacang merah mengandung asam fitat yang berkhasiat sebagai antioksidan sebesar $(13,36-13,38 \mathrm{~g} / \mathrm{kg})^{29}$. 


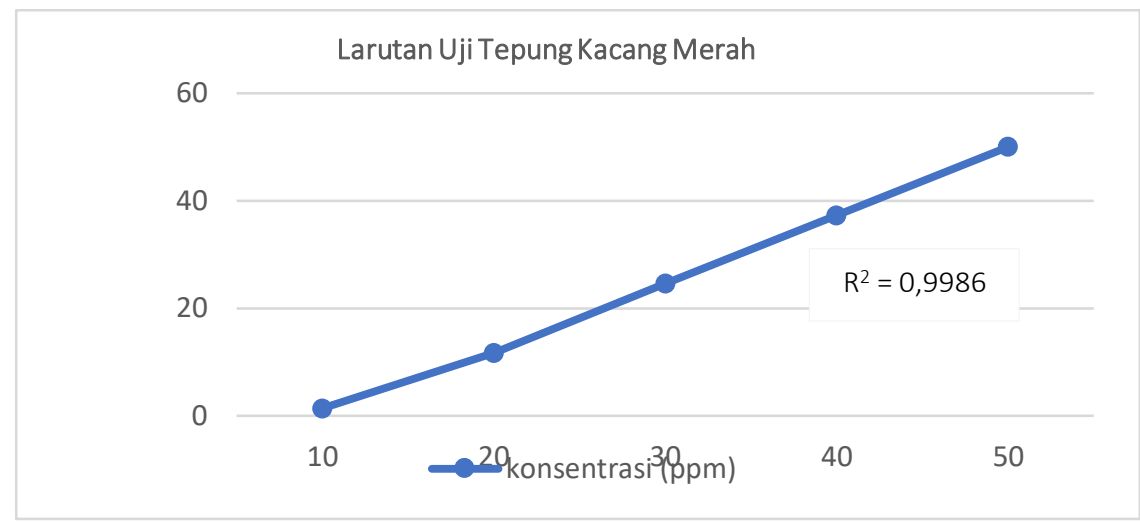

Gambar 6. Grafik konsentrasi dan \%inhibisi Tepung Kacang Merah

Grafik pada Gambar 6 menunjukkan bahwa persamaan regresi linier yang dihasilkan memiliki koefisien korelasi $R^{2}=0,9986$. Nilai $R^{2}$ menggambarkan linieritas konsentrasi terhadap $\%$ inhibisi. Nilai $R^{2}$ yang mendekati 1 menandakan bahwa dengan bertambahnya konsentrasi sampel, semakin meningkat pula aktivitas antioksidannya. Persamaan regresi linier dihitung menggunakan Ms. Excel dengan hasil y $=1,2274 x+(-$ 11,8203 ) sehingga diperoleh nilai $I C_{50}$ sebesar $50,36 \mathrm{ppm}$. Berdasarkan hasil nilai $I_{50}$ tersebut artinya sampel tepung kacang merah memiliki aktivitas antioksidan yang kuat karena nilai $\mathrm{IC}_{50}$ berkisar antara $50-100 \mathrm{ppm}^{28}$. Aktivitas antioksidan tepung kacang merah pada penelitian ini mendekati penelitian yang dilakukan oleh
(Wayan, 2019) yaitu kacang merah memiliki aktivitas antioksidan sebesar 53,91-65,10 ppm $^{30}$.

Aktivitas antioksidan pada snack bar penelitian ini diduga didapat dari kandungan antosianin dari tepung ubi jalar ungu dan asam fitat serta senyawa flavonoid dari tepung kacang merah. Aktivitas antioksidan pada snack bar penelitian ini memiliki intensitas yang sama kuatnya dengan sampel tepung ubi jalar ungu. Hal ini diduga terjadi karena pada snack bar formula terpilih ini digunakan tepung ubi jalar ungu sebesar $70 \mathrm{~g}$ dan tepung kacang merah sebesar $30 \mathrm{~g}$, sehingga sumbangan aktivitas antioksidan pada snack bar formula terpilih mendekati hasil dari nilai IC50 pada tepung ubi jalar ungu. Hasil absorbansi dan \% inhibisi snack bar dilihat pada Tabel 10.

Tabel 10. Hasil Absorbansi Dan \% Inhibisi Uji Aktivitas Antioksidan Snack bar

\begin{tabular}{llll}
\hline Konsentrasi (ppm) & Absorbansi & \% Inhibisi & IC50 (ppm) \\
\hline Blanko & 0,8329 & - & \\
10 & 0,6421 & 22.9079 & $38,0821 \mathrm{ppm}$ \\
20 & 0,5363 & 35,6105 & \\
30 & 0,4652 & 44,1109 & \\
40 & 0,3446 & 58,6264 & \\
50 & 0,2804 & 66,3344 & \\
\hline
\end{tabular}

Berdasarkan tabel 10 diketahui bahwa konsentrasi sampel yang bertambah juga mempengaruhi absorbansi sampel menjadi semakin menurun dan meningkatkan \% inhibisi. Penurunan absorbansi tersebut disebabkan karena elektron DPPH yang tidak berpasangan mengikat atom hidrogen yang disumbangkan oleh sampel snack bar, hal tersebut sekaligus mengakibatkan terjadinya pemudaran warna DPPH dari ungu tua menjadi kuning ${ }^{26}$. Grafik aktivitas antioksidan pada sampel snack bar dapat diamati pada Gambar 7 di bawah ini.

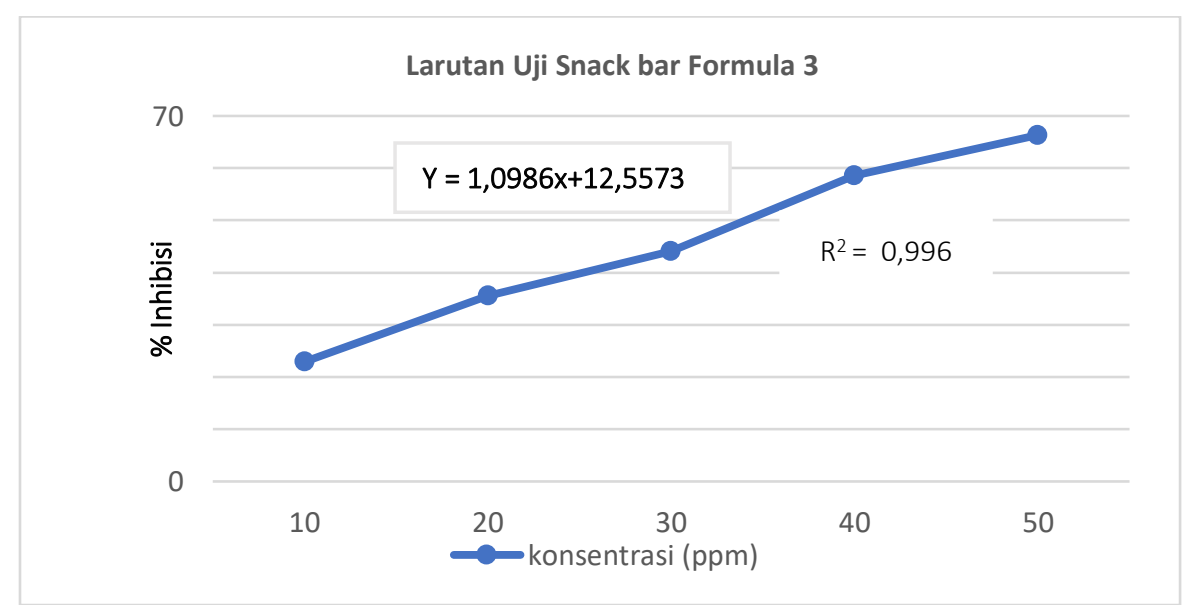

Gambar 7. Grafik konsentrasi dan \%inhibisi Snack bar 
Berdasarkan grafik pada Gambar 7 tdapat diamati bahwa persamaan regresi linier yang dihasilkan memiliki koefisien korelasi $R^{2}=0,996$. Persamaan regresi linier yang dihitung menggunakan Ms. Excel mendapatkan hasil $y=1,0986 x+12,5573$ sehingga diperoleh nilai IC50 sebesar 34,0821ppm. Berdasarkan hasil nilai $\mathrm{IC}_{50}$ tersebut artinya sampel snack barmemiliki aktivitas antioksidan yang sangat kuat ${ }^{28}$. Hasil aktivitas antioksidan pada sampel snack bar ini didukung dengan hasil penelitian yang dilakukan oleh (Nuryanti dkk, 2019) yang menyatakan bahwa aktivitas antioksidan pada snack bar ubi jalar ungu dan kacang hijau berkisar antara 13.14 - $24.60 \mathrm{ppm}^{31}$. Pada penelitiannya dikatakan bahwa semakin banyaknya penambahan tepung ubi jalar ungu pada snack bar, maka nilai $I_{50}$ pada snack bar tersebut semakin kecil yang artinya semakin tinggi aktivitas antioksidan atau semakin aktif suatu sampel uji sebagai senyawa penangkap radikal bebas. Selain dari bahan utama, sumbangan antioksidan terdapat pula dari bahan tambahan yaitu kurma. Aktivitas antioksidan pada buah kurma ajwa adalah sebesar 4,650 ppm $^{32}$ yang termasuk sangat kuat sehingga dapat diketahui snack bar pada penelitian ini memiliki aktivitas antioksidan yang sangat kuat karena sumbangan dari bahan utama dan bahan penyusunnya. Makanan selingan berupa snack bar yang memiliki aktivitas antioksidan yang tinggi sangat baik untuk dikonsumsi oleh penderita diabetes mellitus tipe 2, hal ini dikarenakan antioksidan dapat membantu meminimalisir stress oksidatif yang dapat meningkatkan auto oksidasi glukosa, asam amino dan lipid yang dapat memicu komplikasi pada DM tipe $2^{33}$.

\section{Kadar Antosianin}

Antosianin merupakan pigmen atau zat warna alami yang terdapat pada ubi jalar ungu. Antosianin termasuk kedalam pigmen kelompok flavonoid yang menghasilkan warna jingga, merah dan biru yang bersifat larut dalam air dan mudah mengalami degradasi. Antosianin mudah terdegradasi oleh $\mathrm{pH}$, cahaya, suhu, dan penambahan gula12,34. Penetapan kandungan antosianin bertujuan untuk mengkaji kandungan antosianin pada produk olahan tepung ubi jalar ungu (Ipomoea batatas L) dan snack bar formula 3. Kadar antosianin yang terdapat pada tepung ubi jalar ungu dan snack bar formula 3 dapat dilihat pada tabel berikut

Tabel 11. Kadar Antosianin Pada Tepung Ubi Jalar Ungu Dan Snack bar Formula 3

\begin{tabular}{ll}
\hline Sampel & Kadar Antosianin (mg/kg) \\
\hline Tepung ubi jalar ungu & 84,12 \\
Snack bar formula 3 & 11,45 \\
\hline
\end{tabular}

Dari tabel diatas dapat diketahui bahwa kadar antosianin antara tepung ubi jalar ungu dengan snack bar formula 3 berbeda. Berdasarkan hasil analisis, sampel tepung ubi jalar ungu memiliki kadar antosianin yang lebih tinggi daripada snack bar formula 3 , hal ini terjadi dikarenakan proses pengolahan snack bar yang menggunakan pemanggangan 2 tahap yaitu pemanasan pada suhu $100^{\circ} \mathrm{C}$ selama 40 menit, dan suhu $120^{\circ} \mathrm{C}$ selama 20 menit. Panas yang tinggi dengan waktu pemanasan yang cukup lama mampu menyebabkan kadar antosianin yang terdapat di dalam bahan rusak atau berkurang ${ }^{7}$, namun kadar antosianin pada snack bar formula 3 masih termasuk cukup tinggi yaitu $11,45 \mathrm{mg} / \mathrm{kg}$. Hasil studi menunjukkan bahwa pemberian ekstrak etanol umbi jalar ungu dapat mencegah stress oksidatif dan menurunkan kadar glukosa darah pada tikus percobaan, hal tersebut diduga karena kandungan antosianin yang tinggi yang terdapat pada ubi jalar ungu ${ }^{35,36}$.

\section{Kadar Serat Pangan}

Serat adalah jenis polisakarida yang tidak resisten terhadap enzim pencernaan di usus halus namun dapat difermentasi di dalam usus besar. Hasil analisis menunjukkan snack bar formula 3 mengandung serat dengan dengan kadar $16,32 \%$ sehingga dapat disimpulkan bahwa snack bar yang dihasilkan termasuk kedalam kategori pangan tinggi serat ${ }^{37}$. Hasil analisis yang diperoleh pada penelitian ini lebih besar daripada hasil studi yang dilakukan oleh Rachmayani dkk (2017) yang membuat snack bar dari tepung ampas tahu dan tepung ubi ungu yang menyatakan bahwa snack bar formula terpilihnya mengandung serat pangan sebesar $13,87 \%{ }^{38}$.
Hasil studi menunjukkan bahwa terdapat hubungan erat antara asupan serat dengan kadar glukosa darah yaitu semakin tinggi asupan serat maka kadar glukosa darah semakin dapat dikontrol ${ }^{39,40}$ sehingga snack bar ini dapat menjadi selingan yang cocok untuk dikonsumsi oleh penderita DM.

\section{KESIMPULAN}

Kesimpulan yang dapat diperoleh dari hasil penelitian ini adalah pertama, Snack bar tepung ubi jalar ungu dan tepung kacang merah formula 3 dengan konsentrasi tepung ubi jalar ungu : tepung kacang merah (70:30) adalah formula terbaik berdasarkan uji hedonik oleh panelis. Kedua, Snack bar terpilih (formula 3) memiliki mutu fisik dan kimia yang sesuai dengan persyaratan mutu serta mengandung protein yang tinggi, lemak yang rendah, serta serat tinggi yang baik untuk dikonsumsi oleh penderita diabetes mellitus. Snack bar ini juga memiliki aktivitas antioksidan yang sangat kuat karena kandungan antosianinnya yang tinggi serta mengandung gula reduksi yang rendah sehingga snack bar ini layak untuk dikonsumsi oleh penderita diabetes mellitus.

\section{ACKNOWLEDGEMENT}

Penulis mengucapkan terimakasih kepada Lembaga Layanan Dikti (LL Dikti) Wilayah IV dan Lembaga Penelitian dan Pengabdian pada Masyarakat (LPPM) Universitas Pakuan yang telah membantu terlaksananya penelitian ini serta kepada Direktorat Riset dan Pengabdian Masyarakat (DRPM) yang telah mendanai 
penelitian

ini

hingga

selesai.

CONFLICT OF INTEREST AND FUNDING DISCLOSURE

Semua penulis tidak memiliki conflict of interest terhadap artikel ini. Penelitian ini didanai oleh Direktorat Riset dan Pengabdian Masyarakat (DRPM.

\section{REFERENSI}

1. American Diabetes Association. Diagnosis and classification of diabetes mellitus. (2011) doi:10.2337/dc11-S062.

2. WHO. Global Report on Diabetes. (2016). http://www.who.int/about/licensing/copyright form/index.html\%0Ahttp://www.who.int/abo ut/licensing/copyright_form/index.html\%0Ahtt ps://apps.who.int/iris/handle/10665/204871\%0 Ahttp://www.who.int/about/licensing/ (2016).

3. Badan Penelitian dan Pengembangan Kemenkes RI. Riset Kesehatan Dasar 2013. Riset Kesehatan Dasar (2013) doi:10.1517/13543784.7.5.803.

4. International Diabetes Fedration. IDF Diabetes Atlas Seventh Edition. Circulation research (2015). doi:10.1161/01.RES.31.4.473.

5. Ekawati, P., Rostiati \& Syahraeni. Aplikasi Ekstrak Kulit Buah Naga Sebagai Pewarna Alami Pada Susu Kedelai Dan Santan. J. Agrotekbis 3, 198205 (2015).

6. Cortez, R., Luna-Vital, D. A., Margulis, D. \& Gonzalez de Mejia, E. Natural Pigments: Stabilization Methods of Anthocyanins for Food Applications. Compr. Rev. Food Sci. Food Saf. 16, 180-198 (2017).

7. Husna, N. El, Novita, M. \& Rohaya, S. Kandungan Antosianin dan Aktivitas Antioksidan Ubi Jalar Ungu Segar dan Produk Olahannya. Agritech 33, 296-302 (2013).

8. Avianty, S. \& Ayustaningwarno, F. Indeks Glikemik Snack Bar Ubi Jalar Kedelai Hitam sebagai Alternatif Makanan Selingan Penderita Diabetes Melitus Tipe 2. J. Apl. Teknol. Pangan 3, 98-102 (2014).

9. Direktorat Jenderal Kesehatan Masyarakat. Tabel komposisi Pangan Indonesia 2017. (2018).

10. Marsono, Y., Wiyono, P. \& Noor, Z. Indeks glisemik kacang-kacangan. Teknol. dan Ind. Pangan XIII, 211-216 (2002).

11. Badan Pengawas Obat dan Makanan Republik Indonesia. Peraturan Kepala Badan Pengawas Obat dan Makanan Republik Indonesia Nomor HK.03.1.23.11.11.09909 Tahun 2011 Tentang Pengawasan Klaim dalam Label dan Iklan Pangan Olahan. Badan Pengawas Obat dan Makanan (2011) doi:10.1017/CB09781107415324.004.

12. Hardoko, Hendarto, L. \& SIregar, T. M. Pemanfaatan Ubi Jalar Ungu (Ipomea batatas L. Poir) sebagai Pengganti Sebagian Tepung Terigu dan Sumber Antioksidan pada Roti Tawar. J. Teknol. dan Ind. Pangan 21, (2010).

13. Sutedja, A. M., Trisnawati, C. Y., Candra, A. L. \& Advista, M. Karakterisasi Tepung Kacang Merah Pregelatinisasi dengan Metode Pengeringan Oven dan Sangrai serta Efeknya pada Tekstur Cake non Gluten. Agroteknologi 09, 36-44
(2015).

14. Carella, H. Formulasi Food Bar Sebagai Snack Bagi Penderita Diabetes Mellitus Berbahan Ubi Jalar Ungu (Ipomoea batatas L. Poir) dan Kacang Merah (Phaseolus vulgaris L.) Pratanak Dilihat dari Kadar Amilosa dan Gula Reduksi. (Universitas Muhammadiyah Surakarta, 2016).

15. Permenkes RI. Angka Kecukupan Gizi yang Dianjurkan Bagi Bangsa Indonesia. (2013).

16. Husnah, S. Pembuatan Tepung Ubi Jalar Ungu (Ipomoea batatas varietas Ayamurasaki ) Dan Aplikasinya Dalam Pembuatan Roti Tawar. (2010).

17. Ayu, D. C. \& Yuwono, S. S. Pengaruh Suhu dan Lama Perendaman terhadap SIfat Fisik Kimia Tepung Kimpul ( Xanthosoma Sagittifolium ). J. Pangan dan Agroindustri 2, 110-120 (2014).

18. Ambarsari, I., Sarjana \& Choliq, A. Rekomendasi Dalam Penetapan Standar Mutu Tepung Ubi Jalar. Balai Pengkaj. Teknol. Pertan. Jawa Teng. (2009) doi:10.21776/ub.ijhn.2015.002.02.1.

19. Asfi, W. M., Harun, N. \& Zalfiatri, Y. Pemanfaatan Tepung Kacang Merah dan Pati Sagu Pada Pembuatan Crackers. JOM Faperta UR 4, 1-12 (2017).

20. Natalia, D. Sifat Fisikokimia dan Indeks Glikemik Berbagai Produk Snack. (Institut Pertanian Bogor, 2010).

21. Badan Standarisasi Nasional. SNI Biskuit. (2011).

22. Kurniasih, S. Perbandingan Kandungan Mineral Dan Vitamin B1 Beberapa Jenis Ubi Jalar ( Ipomoea batatas L .). 200-206 (2015).

23. Wisaniyasa, N. W. \& Suter, I. K. Kajian Sifat Fungsional dan Kimia Tepung Kecambah Kacang Merah ( Phaseolus vulgaris I.) Study of Functional and Chemical Properties of Red Bean (Phaseolus vulgaris L.) Sprouts Flour. 3, 26-34 (2016).

24. Soelistijo, S. et al. Konsesus Pengelolaan Dan Pencegahan Diabetes Melitus Tipe2 Di Indonesia 2015. Perkeni (2015).

25. Nindrayani, A. K., Sutardi \& Suparmo. Karakteristik Kimia, Fisik, dan Inderawi Tepung Ubi Jalar Ungu (Ipomoea batatas Poiret) dan Produk Olahannya. Agritech 31, 273-280 (2011).

26. Syaifuddin. Uji Aktivitas Antioksidan Bayam Merah (Alternanthera amoena Voss.) Segar dan Rebus dengan Metode DPPH. (Universitas Islam Negeri Walisongo, 2015).

27. Ginting, E., Utomo, J. S., Yulifianti, R. \& Jusuf, M. Potensi Ubi Jalar Ungu sebagai Pangan Fungsional. Iptek Tanam. Pangan 6, (2015).

28. Molyneux $P$. The use of the stable free radical diphenylpicryl-hydrazyl (DPPH) for estimating anti-oxidant activity. Songklanakarin J. Sci. Technol. 26, 211-219 (2004).

29. Arinanti, M. Potensi Senyawa Antioksidan Alami Pada Berbagai Jenis Kacang. Ilmu Gizi Indones. 1, 134-143 (2018)

30. Wisaniyasa, N. W. Flavonoid Dan Aktivitas Antioksidan Kacang Merah ( Phaseolus Vulgaris L .) Pada Berbagai Lama Waktu Perkecambahan. Sci. J. Food Technol. 6, 83-88 (2019). 
31. Nuryanti, A. D., Melani, V., Kuswari, M., Ronitawati, P. \& Angkasa, D. Pemanfaatan Tepung Ubi Ungu dan Tepung Kacang Hijau dalam Pembuatan Snack Bar Olahraga. J. Chem. Inf. Model. 53, 1689-1699 (2019).

32. Nazilah, N. R. K. Uji Aktivitas Antioksidan dan Skrining Potensi Antikanker Ekstrak Metanol Buah Kurnal Ajwa (Phoenix dactylifera). (2019).

33. Sabuluntika, N. \& Ayustaningwarno, F. Kadar Beta-Karaoten, Antosianin, Isoflavon, dan Aktivitas Antioksidan Pada Snack Bar Ubi Jalar Kedelai Hitam sebagai Alternatif Makanan Selingan Penderita Diabetes Mellitus Tipe 2. J. Nutr. Coll. 2, 689-695 (2013).

34. Priska, M., Peni, N., Carvallo, L. \& Ngapa, Y. D. Review: Antosianin dan Pemanfaatannya. Cakra Kim. Indones. 6, 79-97 (2018).

35. Made Jawi, I., Wayan Putu Sutirta-Yasa, I., Ngurah Suprapta, D. \& Nova Mahendra, A. Hypoglycemic and Antioxidant Activities of Balinese Purple Sweet Potato (Ipomoea Batatas L) in Induced-Diabetic Rats. CIBTech J. Pharm. Sci. 1, 1-6 (2012).

36. Yasa, I. W. P. S., Jawi, I. M. \& Mahendra, A. N. Ethanol Extract of Purple Sweet Potato Tubers
(Ipomoea batatas L) Decreases Blood Glucose and Increase Total Antioxidant Level in Rats with High Glucose Intake. 10, 52-56 (2013).

37. Badan Pengawas Obat dan Makanan Republik Indonesia. Peraturan Kepala Badan Pengawas Obat Dan Makanan Republik Indonesia Nomor 13 Tahun 2016 Tentang Pengawasan Klaim Pada Label Dan Iklan Pangan Olahan. Bpom (2016) doi:10.1017/СВ09781107415324.004.

38. Rachmayani, N., Rahayu, W. P., Faridah, D. N. \& Syamsir, E. Snack Bar Tinggi Serat Berbasis Tepung Ampas Tahu (Okara) Dan Tepung Ubi Ungu. Jurnal Teknologi dan Industri Pangan vol. 28 139-149 (2017).

39. Rl, F. \& Wirawanni, Y. Asupan energi, Karbohidrat, Serat, Beban Glikemik, Latihan Jasmani, dan Kadar Gula Darah pada Pasien Diabetes Mellitus Tipe 2. Media Med. Indones. 46, 121-131 (2012).

40. Kurniasari, R. Hubungan Asupan Karbohidrat, Lemak, dan Serat dengan Kadar Glukosa Dan Trigliserida Darah pada Pasien DM Tipe II Rawat Inap di RSUP H. Adam Malik Medan. Wahana Inov. 3, 163-167 (2014). 